\title{
Cartography in dispute: the frontiers of Brazil in Abbé Raynal's Histoire des Deux Indes
}

\author{
Junia Ferreira Furtado \\ Universidade Federal de Minas Gerais / Universidade Federal de São Paulo \\ e-mail: juniaf@ufmg.br \\ ORCID iD: https://orcid.org/0000-0001-6754-6460
}

Submitted: 3 February 2020. Accepted: 25 October 2020.

\begin{abstract}
This article analyzes the frontier line(s) of Brazil proposed by the Portuguese ambassadors (D. Vicente de Sousa Coutinho, D. Rodrigo de Sousa Coutinho, and Luís de Sousa Coutinho, the Viscount of Balsemão), drawn on maps and documents sent to Abbé Raynal when he was preparing the 1780 edition of his famous Histoire des Deux Indes. This was accompanied by an Atlas de Toutes les Parties Connues du Globe Terrestre, produced by the French geographer Rigobert Bonne. The objective is, in light of the Treaty of Santo Ildefonso, to compare the lines defended by the ambassadors and those which Raynal and Bonne drew on the map of South America in the Atlas, analyzing the geopolitical impacts.
\end{abstract}

KEYWORDS: Histoire des Deux Indies; Raynal; Diplomacy; Frontiers; South America; Santo Ildefonso Treaty; Cartography; Maps.

Citation / Cómo citar este artículo: Furtado, J. F. (2021) "Cartography in dispute: the frontiers of Brazil in Abbé Raynal's Histoire des Deux Indes." Culture \& History Digital Journal, 10 (2): e019. https://doi.org/10.3989/chdj.2021.019

RESUMEN: Cartografía en disputa: las fronteras de Brasil en la Histoire des deux Indes, por el abate Raynal.Este artículo analiza las líneas fronterizas brasileñas propuestas por los embajadores portugueses (D. Vicente de Sousa Coutinho, D. Rodrigo de Sousa Coutinho y Luís de Sousa Coutinho, vizconde de Balsemão), que dibujaron en mapas y documentos enviados al abate Raynal, cuando estaba preparando la edición de 1780 de su famosa Histoire des Deux Indes. Esta fue acompañada por el Atlas de Toutes les Parties Connues du Globe Terrestre, producido por el geógrafo francés Rigobert Bonne. El objetivo es, a la luz del Tratado de Límites de San Ildefonso, comparar las líneas defendidas por los embajadores y lo que Raynal y Bonne dibujaron en el mapa de América del Sur en el Atlas, analizando sus impactos geopolíticos.

PALABRAS CLAVE: Histoire des deux Indies; Raynal; Diplomacia; Frontera; América del Sur; Tratado de San Ildefonso; Cartografía; Mapas.

Copyright: $\odot 2021$ CSIC. This is an open-access article distributed under the terms of the Creative Commons Attribution 4.0 International (CC BY 4.0) License. 
Between May and July 1777, Abbé Raynal (Guillaume Thomas François Raynal, 1713/1796) visited England. His purpose was to collect material for the new expanded and revised edition of his famous Histoire Philosophique des Établissements et du Commerce des Européens dans les Deux Indes, to be published in 1780 (Raynal, 1780). On this occasion he met Luís Pinto de Sousa Coutinho (1735-1804), $1^{\text {st }}$ Viscount of Balsemão, who since 1774 had been the Envoy Extraordinary and Plenipotentiary Minister of Portugal in London (Furtado and Monteiro, 2019, pp. 10-11). Balsemão was also a respected intellectual, especially after providing information to the English historian William Robertson (1721-1793) for the third volume of his 1777 The History of America (Goggi, 2000, pp. 298-302). The meeting with Balsemão, to whom Abbé Raynal referred as "the Portuguese Minister", occurred around $20 \mathrm{July}$, the date when both dined in the house of Fanny, widow of Admiral Boscawen (Aspinall-Oglander, 1942, pp. 87-88; Goggi, 2000, p. 380, 2010, pp. 300-301). The Abbé was very impressed and stated that said that Balsemão was "one of the most enlightened men who ever lived in Brazil" (Raynal, 1780, 9, p. 413), giving him a questionnaire on Brazil, the same as those he distributed to different informants of his confidence and which became one of the principal sources for the revision of his work (Feugère, 1970, pp. 175-200; Goggi, 2010, pp. 296298; Furtado and Monteiro, 2019, pp. 9-10).

Balsemão answered Raynal's questions in a text entitled Extrait des Notes Fournie à Mr. L'Abbé Raynal par S. Excellce. Mr. Le Vicomte de Balsemão sur les Colonies Portugaises, avec ses Observations Critiques sur l'Histoire Philosophique des deux Indies. In it was included a preamble about the history of the border disputes between Portugal and Spain, with an evidently pro-Portuguese tone, which he called Mémoires de son Excellence Mr. Louis Pinto de Sousa Coutinho, Vicomte de Balsemão. Sur les Contestations entre les Couronnes d'Espagne et Portugal, Relatives à ses Possessions dans l'Amérique Méridionale, selon les Epoques et les Traités. ${ }^{1}$ The two documents contain, in a pro-Portuguese perspective, in addition to many descriptive topics about Brazil, the history of the negotiations of its borders with Spain and a description of the frontier line and the subdivision of the territory into captaincies (Furtado and Monteiro, 2019 , pp. 17-20). Raynal was preparing the $3^{\text {rd }}$ of his Histoire des Deux Indes and as Cañizares-Esguerra points out his book was exemplary in the process of European writers "who in the last quarter of the eighteenth century began to call into question the credibility of reports not written by trained "philosophical travelers"" to write the history of the New World as was the case of Balsemão and dom Rodrigo, whose reports eluded his literary traditional sources (pilots, militaries, religious, etc.) used in the previous editions (Cañizares-Esguerra, 2001, p. 12).

Shortly afterwards, in June 1779, it was the turn of the young D. Rodrigo de Sousa Coutinho (1745-1812), who was in Paris on the road to the Court of Sardinia, where he had been appointed Envoy Extraordinary and Minister Plenipotentiary, to meet Raynal. During his time in the city he personally met with the Abbé - meetings which everything indicated that were intermediated by his uncle, the ambassador D. Vicente de Sousa Coutinho (1726-1792) and by the New Christian doctor António Nunes Ribeiro Sanches (1699-1783), exiled in the city (Diniz Silva, 2003, I, p. 80; Goggi, 2010, pp. 296-298).

The first meeting occurred in the palace of Fointainebleau, when they talked "about the colonies of Portugal, notably Brazil", as well as the general situation of France and questions of trade (Diniz Silva, 2003, I, pp. 79-80). Conversation with the young man awoke Raynal's interest, since he arranged a new meeting, this time in Dépôt des Cartes de Paris, belonging to the French navy. The choice was not random. Kept there was a magnificent collection of maps, while since 1775 the French navy's first hydrographer, Rigobert Bonne (1727-1794), also worked there (Brown, 2010, pp. 39-41). Bonne was producing Atlas de Toutes les Parties Connues du Globe Terrestre (Bonne and Raynal, 1780; Kantor, 2016, pp. 503-522) to accompany a new edition of Histoire des Deux Indes. This second meeting allowed the consultation of the vast collection of maps kept there, in order to give visibility to the territories of the two Crowns in the Americas and clarify Bonne and Raynal's doubt about their frontiers. More than this was involved. On this occasion, to reinforce the interests of Portugal in the Americas, D. Rodrigo "showed the Abbé a 'celebrated and very rare' map from Spanish America of which he was the owner" (Diniz Silva, 2006, II, pp. 99, 4).

The preparation of Atlas raised in Raynal a renewed interest for geography, and the maps became at the same time sources and products linked to the new edition of Histoire des Deux Indies, from 1780. In the case of Southern America, various difficulties impacted the accurate representation of European possessions, particularly in relation to tracing out Brazil's frontiers. On the one hand, the doubts resulting from boundary disputes between the two Iberian Crowns, accentuated during the eighteenth century and which between 1776 and 1779 became explosive (Furtado and Monteiro, 2019, pp. 12-14). On the other hand, France's questioning of the frontier with Guiana in the North Cape (Cabo do Norte), now Amapá (Furtado, 2013 , pp. 305-312). Invasions, territorial disputes, indefinition in negotiations, ignorance of geography, aggravated by the imprecision of maps, prevented Bonne from having certainty about where to trace the frontiers.

Bonne transmitted his geographic doubts to the Abbé and asked for his help. Raynal, in turn, used his network of informers and took advantage of meetings with Balsemão and D. Rodrigo to gain geographic information. Although the two diplomats provided textual and cartographic material about the shape of Brazilian territory, the geographer states in the Introduction to his Atlas, that he "drew the frontiers of Spanish and Portuguese possessions according to the 1778 treaty" (Bonne, 1780, p. 15) -referring to the New Treaty of El Pardo, signed in March of that year, which ratified the Santo Ildefonso Treaty in October 1777 . Not by chance this is the last event in the border disputes with Spain mentioned by Balsemão in the Mémoires he gave the Abbé. 
Bonne's affirmation was at the very minimum a half truth, since drawing the frontiers of Brazil on the maps of the Atlas was a task full of uncertainties. Mirroring the stipulations of the 1778 Treaty between Portugal and Spain, as Bonne stated he had done, was almost an impossible mission, since many of its terms were vague or imprecise. The two Crowns only had a relative knowledge of the geography of the frontier territory, the available maps were omissive and contradictory, and in some cases it was decided that the border would be defined later. In relation to Guiana, the difficulty was in identifying exactly what was the Vicente Pinzón River chosen in Utrecht as the boundary with the French, the difficulty which the French geography Jean Baptiste Bourguignon d'Anville (1697-1782) faced in 1760, since in one of the printed copies of his Amérique meridionále, three possible locations are printed for the bay of this $\operatorname{river}^{2}$ (Fig. 1). The first of these, more favorable to the French, chosen as a border in the original edition (1748), corresponded to the North Cape, which coincided with the Bay of the Vicente Pinzón or Calcuene River; the second, the mouth of the Arawari River, pushed the border a little northwards, alongside the Island of Muracá; the third, the mouth of the River Oiapoque, near Cape Orange, pushed it more to the north, as defended by the Portuguese (Furtado, 2012, p. 289).

Almost 20 years later, when Bonne prepared the maps of the Atlas, the frontiers of Brazil continue to be an open question and the object of bitter geopolitical disputes, which justifies why D. Rodrigo and Balsemão had provided the Abbé (a Frenchman) with Luso-Brazilian maps and documents, since they intended to influence its design. As members of the diplomatic corps they only did this after being authorized by the Portuguese Crown, which perceived in this strategy the possibility of influencing European pub-

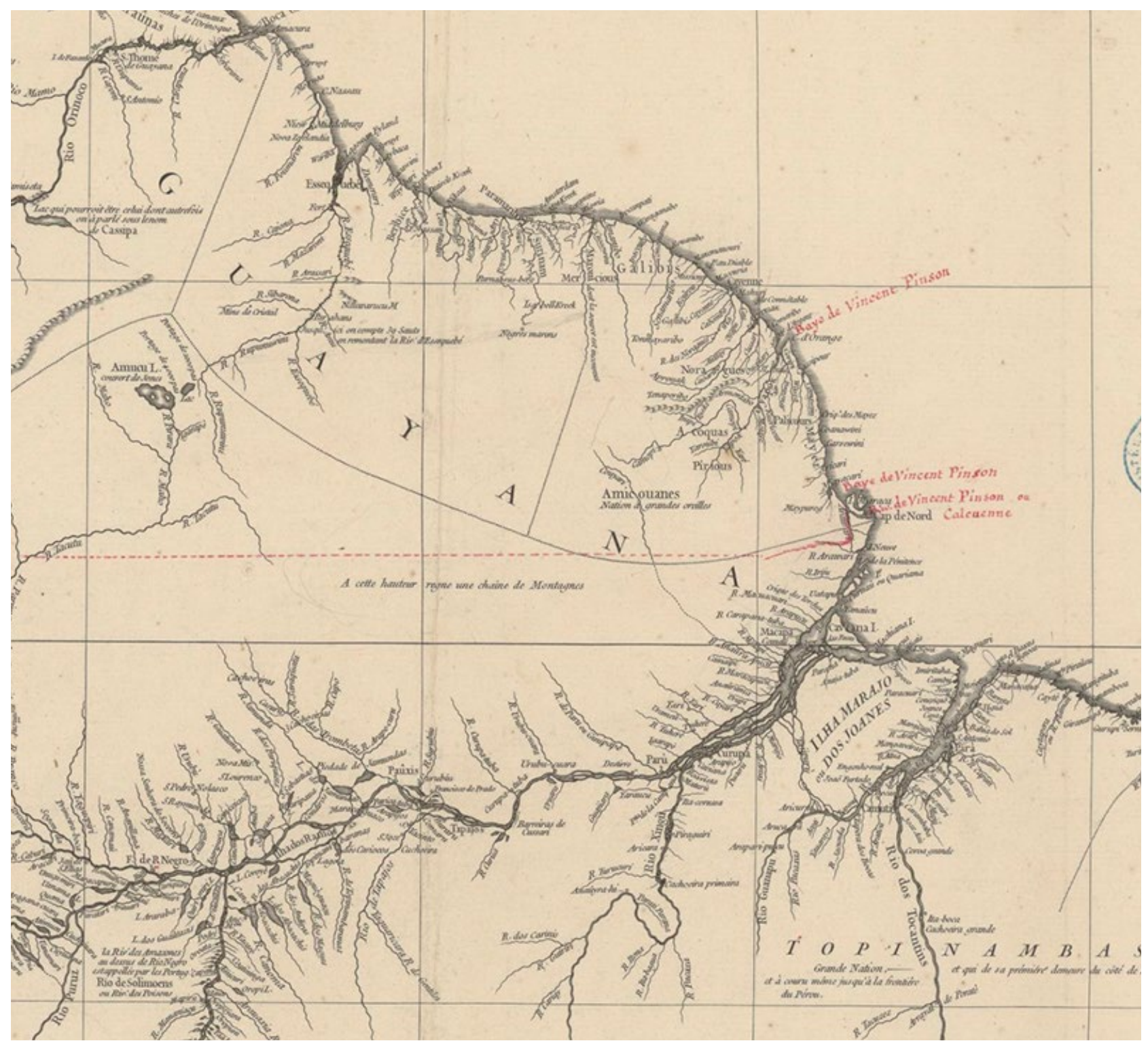

Figure I. Detail of D'Anville's Amérique meridionále, 1749. BNF, DCP, GE DD 2987 (9168B). 
lic opinion in favor of its interests in the questions of borders, since Raynal's book was already a global bestseller (Furtado and Monteiro, 2019, pp. 14-17). However, as will be seen, it was not always possible to totally control the actions and opinions of the ambassadors.

The aim of this article is to compare the frontiers of Brazil proposed by the two ambassadors and those which Bonne and Raynal drew on the map of South America in Atlas de Toutes les Parties Connues du Globe Terrestre, analyzing the geopolitical impacts of each. It starts with the relationship established between the various editions of Histoire des Deux Indes and the maps, since the 1780 one was not the first to use them. Following this, the discussion turns to the context of the frontier disputes and negotiations which preceded them and which were linked to the provision of the texts by Balsemão and the maps by D. Rodrigo. While the document which the former gave to the Abbé has been identified, the same cannot be said about the Spanish map which the latter showed him and for this reason, it is sought to discover what it was. The starting point is how D. Francisco Inocêncio de Sousa Coutinho (1726-1780), then ambassador in Madrid and the artificer of the 1777 and 1778 treatises, used maps to give visibility to frontier territories, allowing him negotiate its borders, and the geopolitical education which he gave to his son, D. Rodrigo, when the latter was in the embassy in Spain, which included the study of cartography. Afterwards the document provided by Balsemão is analyzed. Finally, it is investigated how Raynal and Bonne drew the frontier line in the Atlas, problematizing the way that information passed by the two ambassadors was filtered, since they were not passive receptors of what their informers told them (Furtado and Monteiro, 2016 and 2019). By taking as a starting point that maps are never neutral, but have a "political intentionality and subjectivity, contributing to the process of the definition of these colonial territories" (Furtado, 2012, p. 507), it is discussed which Crowns - Portugal, Spain, or France- benefitted from the shaping of the South American frontiers in the Abbé's book. In this perspective, the maps of the Atlas became spaces of political dispute and reflected, or hid, the strategic interests of European nations in South America.

\section{THE MAPS IN HISTOIRE DES DEUX INDES}

The Histoire des Deux Indes's first edition, published in French in six volumes, dated 1770, is anonymous and gives Amsterdam as the place of publication, but there are indications that it was actually published in Nantes (Aquarone, 1972, p. 86; Muthu, 2003; Israel, 2011, p. 425). Raynal produced two other editions in 1774 and 1780, based on the first but in which he introduced substantial changes in the text, respectively, as well as reprinting it several times" (Furtado and Monteiro, 2016, p. 733; Cañizares-Esguerra, 2001, pp. 35-38). The latter, the first in which Raynal appeared formally as an author, was accompanied by Bonne's Atlas.

However, it was not the first time that an edition of Histoire des Deux Indes had maps. The 1773 apocryphal one, published in Amsterdam, by E. Van Harrevelt and D. J. Changuion, without the supervision of Raynal, was accompanied by Atlas Portatif pour Servir à l'Intelligence de l'Histoire Philosophique et Politique des Établissements et du Commerce des Européens dans les Deux Indes, which "foreshadows an editorial strategy based on the permanent updating of material" (Mackinlay, 2011, p. 682). In this, the maps "were displayed according to the order of the narration" of the text of Histoire des Deux Indes and in its table of contents the "Volumes and corresponding pages, where the places mentioned are represented, were indicated" (Raynal, 1773, p. 4). However, to the contrary of what was expected from an Atlas, where the homogeneity of scales and the proportion between maps is the norm, it is a heterogeneous set, composed of 46 maps with various authors. Most of them are by Jacques-Nicolas Bellin (1703/1772), the hydrographer of the king of France, well known for his maritime charts; others were commissioned by the Count of Maurepas (Jean-Frédéric Phélypeaux, 1701/1781), Louis XV's Minister of the Marine (17101774); and the others by different or anonymous authors, most printed in Amsterdam.

Brazil is represented in four maps, with one having no author and three being copies of maps by d'Anville (Furtado 2012, 2013). The first, anonymous, represents the Northeast region of Brazil (no. 29) ${ }^{3}$ with the date of 1772, having been printed in Amsterdam. Despite the late date, it shows the region according to the maps produced in the previous century, during the Dutch invasion of the Northeast of Brazil (1630-1654), and is basically restricted to the geography of the coast with the interior left as a large vacuum. The durability of this cartography of the interior resulted from the fact that the Portuguese Crown had neglected its geographic survey, since it was located far from the disputed frontiers and the coastal sugar circuits. The last three maps were neither new nor up to date, covering the extreme south (no. 30), ${ }^{4}$ the Southeast (no. 31), ${ }^{5}$ and the Amazonian region (no. 32). ${ }^{6}$ It is stated that the first two were taken from the celebrated Amérique Méridionale by d'Anville, published in Paris in 1748; and the last from his map which illustrated 1745 the book Voyage sur l'Amazone, which describes the expedition of Charles Marie de La Condamine (1701-1774). Except for the Southeast, it contained parts of the southern frontier and the north of Brazil, respectively.

The map of the south of Brazil (no. 30, Fig. 2) shows part of the frontier with the Spanish possessions. The frontier line began at Ponta de Castillos, south of Lake Mirim, and from there ran gradually northwards, turning slightly to the west, until it reached the Paraná River, at the height of the $23^{\text {rd }}$ parallel south, near to the confluence of the Tieté River, one of its tributaries. It was not a configuration favorable to the Portuguese, since it left to the Spanish the entire southern side of the River Plate, including Sacramento Colony (Colônia do Sacramento) - the bone of contention between the two Crowns (Furtado, 2012, pp. 263-276).

The prejudice to Portuguese interests is evident when compared to the other map in this Atlas, the Carte 


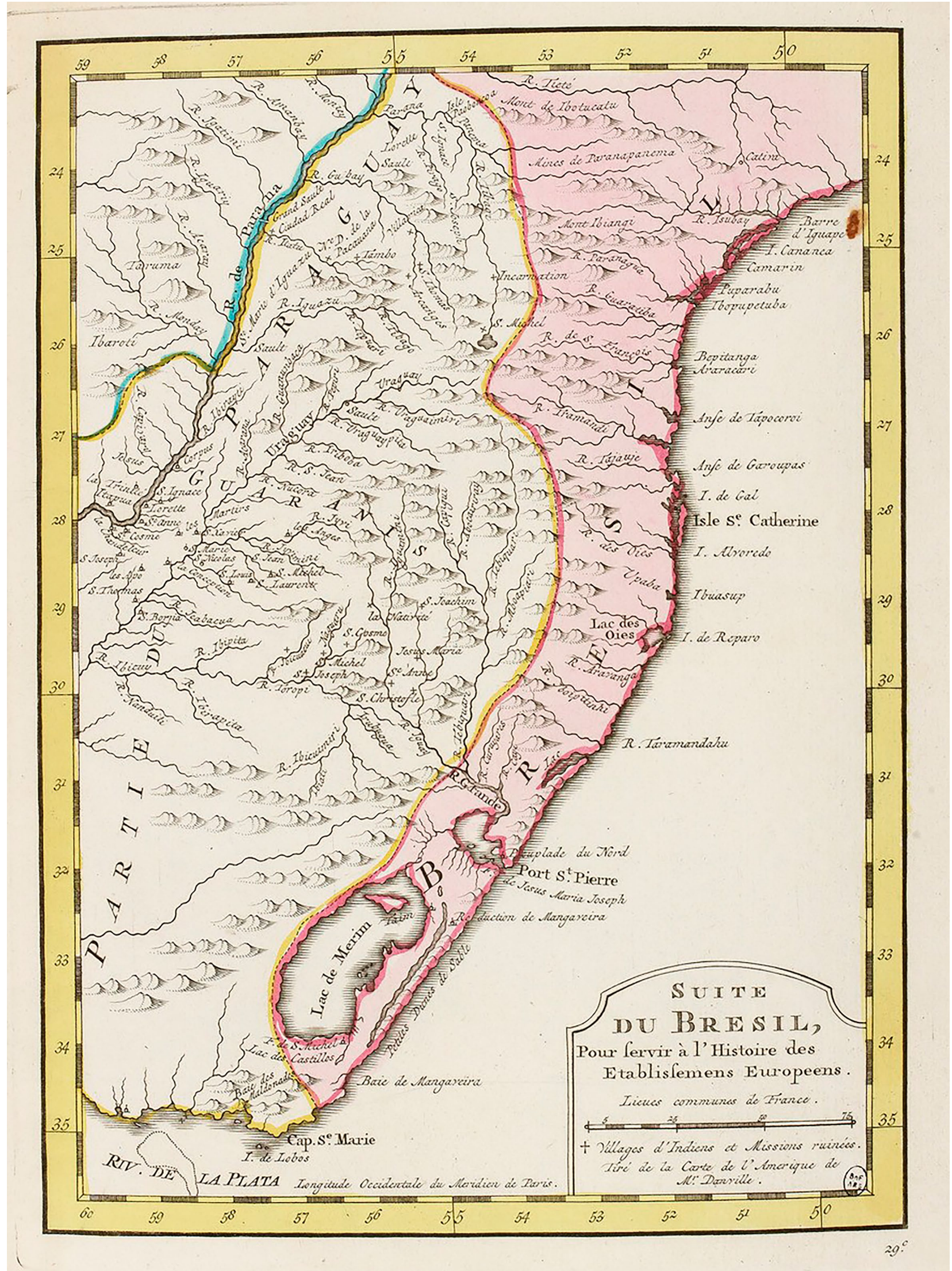

Figure 2. D’Anville, Suite du Brésil, 1749. BNF, DCP, NUMM-1512344. 
du Paraguay et des Pays voisins (no. 28 , Fig. 3 ), ${ }^{7}$ in which the frontier has a much more favorable configuration. This map, with no author, was printed in Amsterdam in 1771, but it was also based on d'Anville's cartography. ${ }^{8}$ Paraguay, the Spanish province where the Jesuit missions were concentrated, was colored yellow, distinguishing it from the surrounding areas which had no colors. This strategy allowed its borders to be visualized: with other Spanish provinces to the west and Brazil to the east, with the part most to the south of the line being reinforced by a red line with the parts between the Uruguay and Iguaçu rivers and the Paraná and Paraguay rivers being dotted. As in the map of the south of Brazil, the most southerly point is in Castilhos, but the line is immediately interiorized, extending northwest until it reaches the sources of the Ibicuí River. It then moves in a straight line to the north, reaching the upper Uruguay river, and from there runs to the middle Iguaçu, when it turns northwest, cutting across the Rio Grande, or the Paraná River, reaching it in the town of Guaira. By way of comparison, on the map of the south of Brazil, the point of the frontier positioned at a longitude of $54^{\circ}$ west is between the $23^{\text {rd }}$ and $24^{\text {th }}$ parallels in Paraguay, this is at latitude $31^{\circ}$, much more to the south. This signifies that, in the latter, much more favorable to the Portuguese, Brazilian territory expands to the west at a much more southern point than in the former, where the line runs for a long distance parallel and close to the coast.
This discrepancy reveals that the criteria for the choice of maps was not political: the editor selected those considered most geographically reliable, without taking into account the political inconsistencies between them.

Despite being taken from d'Anville's Carte $d u$ Cours du Maragnon, the map which represents the Amazonian region (no. 32, Fig. 4), has an instigating modification in relation to the original, which neither used colors nor contained frontier lines. On it, parallel to the coast, which runs between the rivers Essequebé, the most northern point represented, and the mouth of the Amazon, is printed in a large font the toponym Guiane. This region is divided into Hollandoise, Françoise, and Portugaise, printed in a slightly smaller font. Borders are not drawn and between the latter two are the Oyapoq (Oiapoque) and Araûari (Arawari) rivers on the coast. Inland, a chain of mountains is suggested, drawn just above the name Portugaise. This configuration, although imprecise, guaranteed the Luso-Brazilians not only the greater part of the territory of the North Cape, such as the dominion of the two banks of the Amazon and the monopoly of navigation on the river, as negotiated in Utrecht in 1712. These toponyms are reproduced in the copy of the Atlas Portatif, but using different colors this divides the Amazon region into four subregions. All of Guiana is colored pink, suggesting that it is unique geopolitical entity, different from the original, where the names of the colonizers leave clear

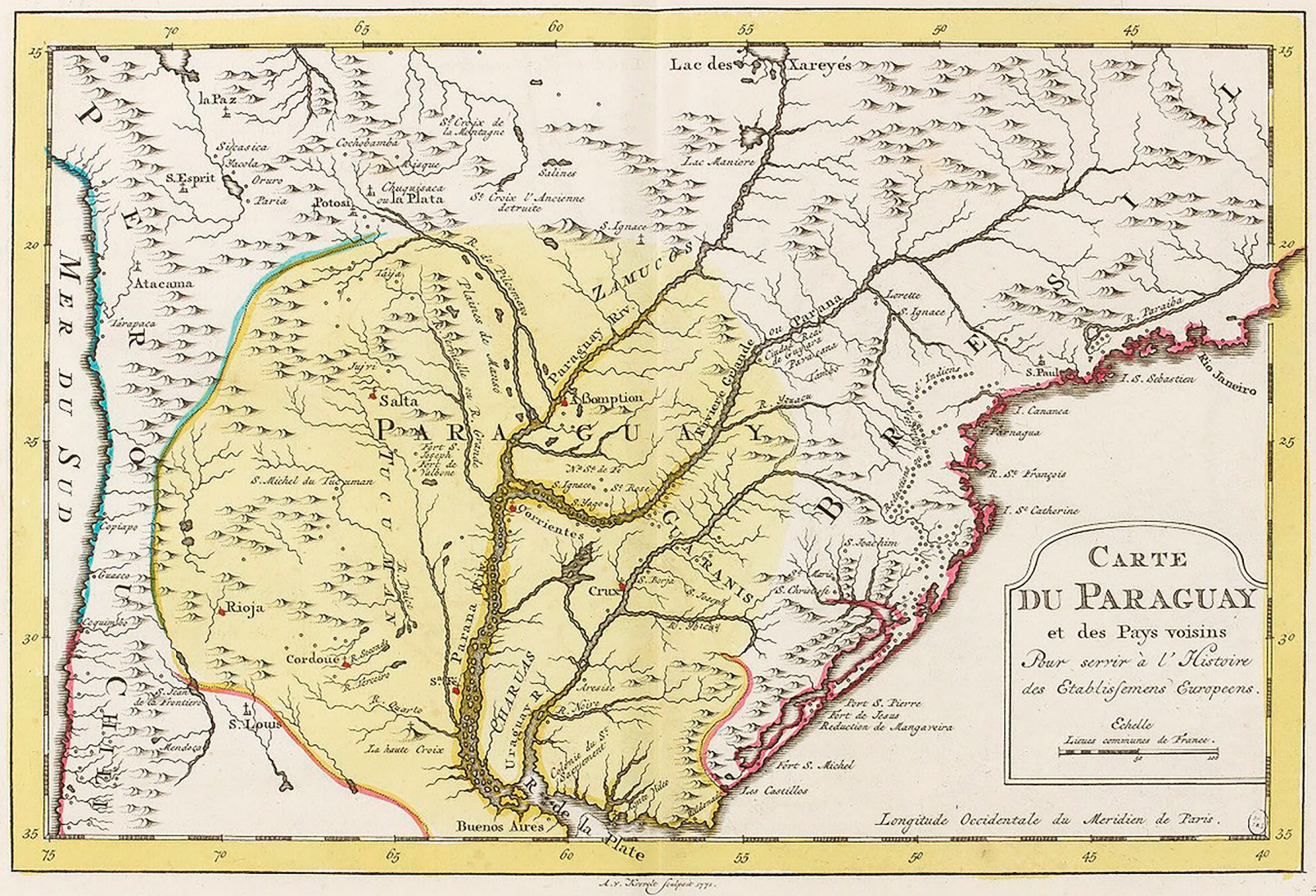

Figure 3. Carte du Paraguay et des Pays voisins, 1772. BNF, DCP, NUMM-1512344. 
its shared possession. As in a map, nothing is inserted or omitted in a random form and "the colors [...] cannot be neglected as a purely decorative ingredient" (Bueno, 2008, pp. 375-383). This strategy completely altered the way the region was perceived by the reader. Bellin, author of many of the maps in this Atlas, had already used colors with this geopolitical function, as in his map of the American continent. As announced in an edition of the gazette Mercure, in his maps the colors allowed the visualization of the possession of different European nations (Furtado, 2012, p. 109). This stratagem seemed to have inspired the editor do Atlas, perhaps Bellin himself, who added colors to the original: pink revealing French expansionism in the territorial extent of the Guianas.

The $2^{\text {nd }}$ edition of the Histoire des Deux Indes in 1774 is anonymous, and also contains an engraving of Raynal after the title page. Directly revised and supervised by the Abbé, who included in it various modifications and additions, it was published in the Hague in Gosse Fils printers and included four maps scattered through the six volumes, two of them printed in duplicate (Raynal, 1774). This time the maps are all by Rigobert Bonne, who presents himself in his cartouches as the 'master of mathematics,' retroacting to this moment the beginning of his collaboration of Raynal. Each map appears associated with and illustrates the region referred to in the volume in which it is inserted. Volumes 1 and 2 reproduce the same map, which covers Europe, the east coast of Africa, Asia, and Oceania. The same happens in 3 and 4, whose map illustrates the Americas - between New Mexico and Patagonia- and the west coast of Africa. In 5, there is a map of the Gulf of Mexico and the Antilles and in 6 one which portrays the western part of North America, including Canada and Greenland.

The map of Southern America (Volumes 3 and 4, Fig. 5) neither contains any frontier lines between Eu- ropean possessions, nor uses colors to suggest this division. Toponyms are used to indicate, roughly speaking, the corresponding European colonial territories. In the south of Brazil, "Paraguay" is situated much to the west, at the height of the island of Santa Catarina, and in the north "Guiane" is written above the Amazon River and the Equator line, permitting Brazilian territory to extend to the two extreme points in the southwest and northeast. The option not to mark the frontier can be the result of the author's intention not to shape the territory according to political criteria, or it could result from the actual indefinition of these borders. In the case of Portugal and Spain, the $1^{\text {st }}$ Treaty of El Pardo in 1761, in force at the time of the publication, abolished the frontiers established in 1750 in the Treaty of Madrid, while France put in doubt the position of the line in the North Cape. For one reason or another, the reader is not induced to take a side in these disputes, the maps serve to illustrate physical geography.

Although these two editions and the quality of their maps must have been a success, they still needed revision due to geopolitical changes occurring in the colonial areas, notably the independence of the USA in 1776, which stimulated the Abbé and his editors to include in the ambitious expanded edition of 1780 a much larger and more homogenous set of maps. Along with the nine volumes of the Histoire des Deux Indes, the Atlas de Toutes les Parties Connues du Globe Terrestre was printed in Geneva by Pellet and published in Paris by Stoupe, Brunet, and Panckoucke. It includes 49 maps, ${ }^{9}$ all produced by Bonne, then the royal hydrographer. Its transitivity with Raynal's work is not only expressed in the title, but also in the fact that the localities mentioned in the Histoire des Deux Indes were marked in the maps where they appear, with an asterisk to "facilitate the research of those [places] which are cited in this Histoire." Among these maps, all produced in the same geographic projection and

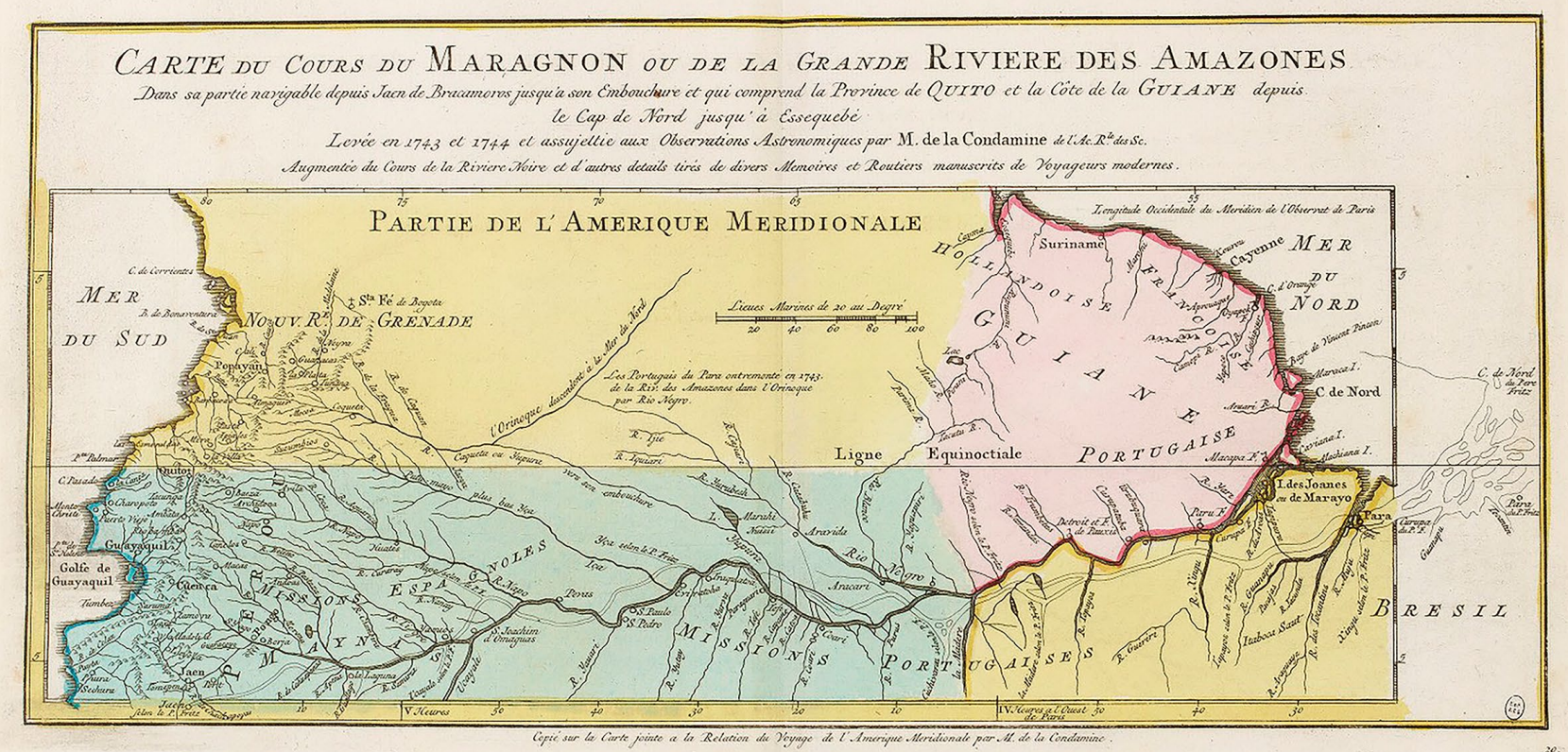

Figure 4. D’Anville, Carte du Cours du Maragnon, 1744. BNF, DCP, NUMM-1512344. 


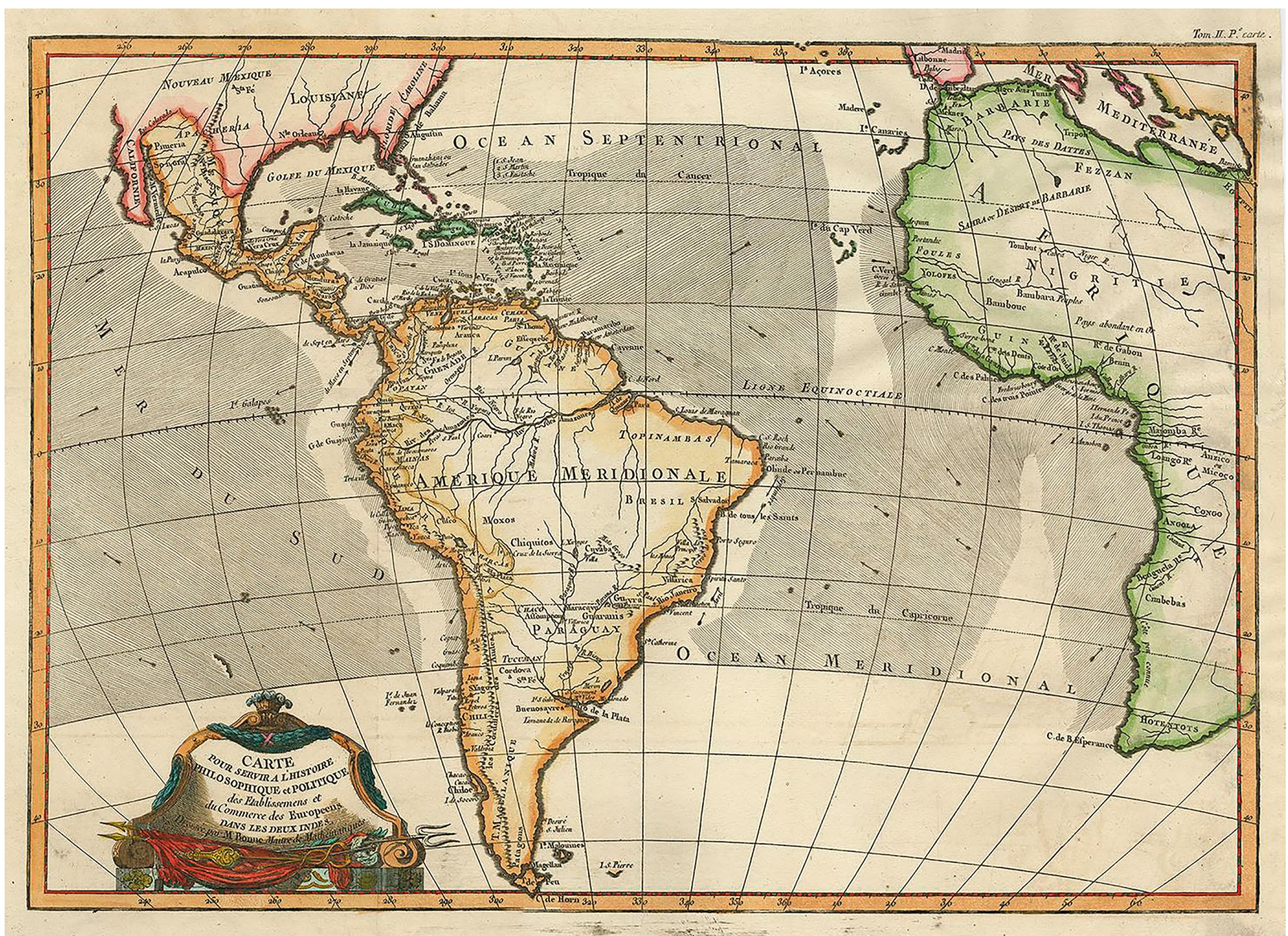

Figure 5. Carte pour servir a l' Histoire Philosophique des Établissements et du Commerce des Européens dans les Deux Indes, 1774.

referenced by the same meridian, giving them uniformity (Bonne and Raynal, 1780, pp. 5-6), seven deal with South America, with one covering the entire continent (no. 29, Fig. 6) and the others Peru (no. 30), the Kingdom of New Granada (no. 31), French Guiana (no. 32), Chile (no. 33), while Brazil is divided into two: south (no. 34) and north (no. 35). To the contrary of the maps of the 1774 edition, the lines of the frontier of Brazil are drawn and to understand its shape it returns to what was stipulated in the eighteenth-century frontier treaties.

\section{THE FRONTIER TREATIES}

The Treaty of Utrecht (1713-1715), which brought an end of the War of Spanish Succession (1701-1713), gave the tone to what during the eighteenth century was disputed and later negotiated between Portugal, Spain, and France in their possessions in the Americas. In relation to Brazil, in the south the Spanish were obliged to return Sacramento Colony, founded in 1680 by the Portuguese on the Southern bank of the River Plate, and in the north to recognize the exclusive dominion of the Luso-Brazilians of both banks of the Amazon, which guaranteed the latter the monopoly of its navigation. The French accepted this final point and defined the Vicente Pinzón River as the frontier with Guiana, allowing the reconstruction of the forts on the north bank of the Amazon, destroyed during the war. However, not all the differences were resolved. "From the second half of the 1720s, the French authorities in Cayenne began to contest the until then consensual understanding that the river mentioned in the Treaty of Utrecht was the Oiapoque" (Santos, 2018, p. 210) and each crown began to indicate a different course of water. Portugal insisted on this river and France on the Araguari or Arawari, more to the south, which benefitted it.

In relation to the Spanish, they wanted to limit the Portuguese territory of Sacramento Colony to a cannon shot and to isolate the Luso-Brazilians, they adopted an aggressive colonizing policy on the northern bank of the River Plate, founding forts in Montevideo and Maldonado. Reaction was not slow to come. From 1736 onwards the Portuguese began a systematic occupation of the South of Brazil, with the construction of forts in Rio Grande and the sending of Azorean colonists to the island of Santa Catarina (1740). They adopted the same policy in the Center-West, dismembering in 1748 the regions of Goiás and Mato Grosso from São Paulo captaincy. These became autonomous captaincies: the first with a capital in Vila Boa and the second in Vila Bela. 


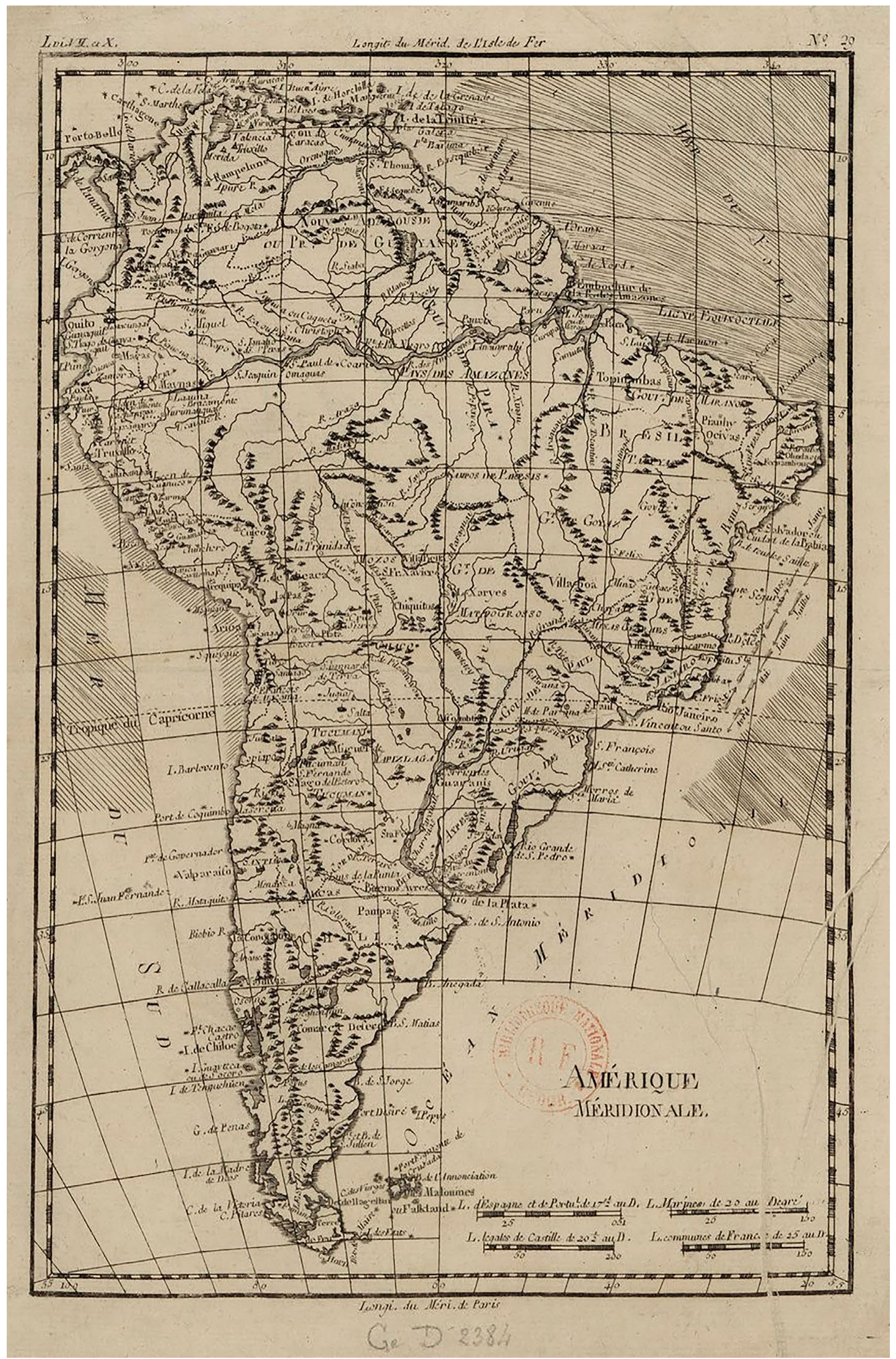

FIGURE 6. Rigobert Bonne and Raynal, Amérique meridionále, 1780. BNF, DCP, H.G.22484v. 
In 1750, Portugal and Spain signed the Treaty of Madrid, where their American frontiers were negotiated in a broader form, with a flagrant advantage for the Portuguese, which guaranteed vast territories in the south, center-west, and north, using the argument of uti possidetis, in other words that possession belonged to those who had colonized the region (which did not always reflect the reality). Sacramento Colony remained Portuguese and the Castilians gave up Sete Povos das Missões, under Jesuit jurisdiction, expanding the limits to the West. Close to the coast, Lake Mirim remained in Brazilian territory and the border line was placed on Ponta de Castilhos. In the center-west, Portuguese dominion over Goiás, Cuiabá, and Mato Grosso was recognized, interiorizing the Brazilian frontiers up to Lake Xarais, or Pantanal (for the Portuguese), located on the Upper Paraguai River, guaranteeing them dominion over the large surrounding rivers (Tocantins, Araguaia, and a large part of the Madeira). In the north, Portuguese possession of both banks of the Amazon was maintained, the culmination of the slow process of the construction of its hegemony. However, these territorial exchanges met strong opposition from both sides and in 1761 the Treaty of El Pardo revoked all its dispositions and at least theoretically, everything returned to the previous situation.

However, it was not exactly this which occurred. In the context of the reign of D. José I (1714-1777), from 1750 onwards, under the command of his principal minister, the Marquis of Pombal (1699-1782), a strong expansionist colonization policy was carried out on the frontiers of Brazil, with the aim of actually constructing $u t i$ possidetis. the captaincy of Rio Grande being established in 1760 and Sacramento Colony was retaken, with its territory being expanded in an agricultural belt after 1763 . In the Center-West, the governors, including Balsemão who governed Mato Grosso from 1769 to 1772, building various settlements and forts, such as Príncipe da Beira, located on the right bank of the Guaporé River (now in the state of Rondônia). In the north, Francisco Xavier de Mendonça Furtado, brother of Pombal, established various villages, with the peak being the foundation of Mariuá, afterwards the vila of Barcelos, on the River Negro. In the North Cape he returned to the project of constructing the vila and fortress of São José de Macapá. For a better understanding and integration of the last two regions, in 1752 fluvial communication between Belém and Vila Bela was authorized, along the axis of the Madeira-Mamoré-Guaporé-Amazonas rivers (Furtado and Paquette, 2019, pp. 519-540).

However, this expansion was disturbed by conflicts, the first provoked by the entrance of Portugal, albeit briefly, in 1762, into the Seven Years War. In October the Spanish took Sacramento Colony, restored in the 1763 Treaty of Paris. However, this was a fleeting victory, because a few months afterwards the Governor of Buenos Aires invaded the captaincy of Rio Grande and destroyed many Portuguese forts. In the center-west/north axis, the confrontations were concentrated on the Guapore River, in the province of Moxos; on the upper Amazonas, near the detachment of the Javari and Tabatinga; in the Madeira river, along which the gold from the center-west flowed; and on the Branco and Negro rivers (Brito, 2018, pp. 105148).

At the end of 1775 , despite a non-aggressive pact, it was the turn of the Portuguese to advance. The Marquis of Pombal launched an offensive in the south of Brazil, retaking the forts of São Martinho (1775), Santa Tecla, and the vila of Rio Grande (1776), alongside Lake Patos. In 1777, in the middle of new negotiations, the Castilians retaliated, taking by assault Santa Catarina island and Sacramento Colony. In this context of intense rivalry, the Portuguese Ministry of Foreign Affairs orchestrated the discourse of its ambassadors in Europe, especially in Madrid, London, and Paris, to conquer the sympathy of these courts and the public opinion of its countries. This is the reasons that its officials became Raynal's informers.

To the contrary of what the French and English expected, the dispute ended with direct separate negotiations between Portugal and Spain, carried out by its ambassador in Madrid, D. Francisco Inocêncio de Sousa Coutinho, father of D. Rodrigo. On $1^{\text {st }}$ October 1777, the Treaty of Santo Ildefonso was finalized and in March of the following year, the New Treaty of El Pardo was signed, ratifying Santo Ildefonso and establishing a non-aggression pact (Furtado and Monteiro, 2019, pp. 12-14). The principal objective of the former was to end conflict and establish peace and roughly speaking defined a border which generally returned to what had been established in the Treaty of Madrid. The exceptions were in the south, with the handing over to the Spanish of Sacramento Colony, the nearby land on the northern bank of the River Plate, Sete Povos das Missões, and the island of São Gabriel on the same River. Navigation on Lake Mirim and the territory of the coastal strip was shared, while the interior border retreated to the Chuí River, continuing northwards in almost a straight line to the Iguaçu River. In the north, the most western part of the course of the Amazon River between the mouth of the Javari and Japurá rivers, whose possession by the Portuguese was questioned, came to be shared by the two Crowns. In turn, Portugal was assured the island of Santa Catarina and the captaincies of Rio Grande, Mato Grosso, Cuiabá, Goiás, Grão-Pará, and the Amazon. ${ }^{10}$

Specifying borders between the two crowns was not an easy task, as various difficulties were interposed, including the lack of knowledge of large parts of the interior of the territory, which the maps consulted did not resolve. D. Francisco complained to the Crown that "I cannot afford the great work that the comparing of maps has cost me, which disagree with each other" 11 and, on various points of the frontier, which ran for around 2500 leagues, ${ }^{12}$ the clauses agreed did not clearly define where the border passed. As a form of postponing a final solution, they created, especially in the north, neutral zones, which would be agreed later by local governors, afterwards to be ratified by binational demarcation parties, as defined in article XV. However, despite these imprecisions, it was believed that "the Treaty, which consisted of 
24 articles, should serve as the basis for a perpetual and indissoluble friendship, and peace and the definition of borders" (Giraldo, 1991, pp. 24-26, 29). The lack of clear borders justified the Portuguese effort, even after the signing of the two treaties, to influence Histoire des deux Indes (Furtado and Monteiro, 2019, pp. 6-35). The maps in the Atlas showed European public opinion the geopolitics of the South American continent according to their wishes. What then was the frontier which D. Rodrigo and Balsemão both defended in their discussions with Raynal?

\section{ON THE EVE OF SANTO ILDEFONSO}

It is necessary to go backwards in time a little. In January 1776, while preparing to negotiate the frontiers of Brazil, D. Francisco assembled in Madrid a collection of Portuguese and Spanish maps, which he used to support the attempt to more clearly define the geographic features along the frontier line. What maps were these? On at least two of these maps sent to Lisbon, he traced out frontier lines, on one with the help of his son.

Some were already in his possession and he gave them new uses. This was the case of the maps of Paraguay and Mato Grosso "which in 1748 he had bought in the library of Jose de Lacerda", produced with their corresponding reports during "some voyages and investigations made" in the two regions. When he negotiated in Aranjuez, staying in one of the royal palaces, in May 1778, he ordered them brought from his house in Madrid, seeking to clarify the frontier geography. Another was a private copy of the Mapa das Cortes, a map that the Treaty of Madrid based on, which according to him, "does not seem to be very exact, unless my weak geographic knowledge is fooling me." Lacking more precise maps, he used it at the beginning of negotiations. Portuguese maps arrived from Lisbon, since he insisted that "for all of the frontier line a very exact map is needed on which, without any mistakes, all the land and rivers are marked." Among these was an original of the Mapa das Cortes, "signed and sealed by the ministers who made the treaty in 1750", whose boundary line was the one that the Portuguese had argued had to be kept in the new agreement. Despite some uncertainties these maps contained strategic geographic information which the Portuguese wanted to keep secret. Warned by the Secretary of State, Aires de Sá e Melo (1715-1786), D. Francisco guaranteed that, "like all my papers, they are always kept under my key, which never leaves my power neither during the day nor the night."13

He also obtained Spanish maps, such as "two maps of South America, printed in 1772 in Madrid" sent at the suggestion of Michele Franzini (1740?-1810), tutor of the royal princes, to Portugal to try to resolved geographic doubts, but which to him appeared "not to be worth anything." Some were shown to him by Marquis of Grimaldi (Pablo Jerónimo Grimaldi y Pallavicini, 1720-1789), chief minister of Spain, when both tried to resolve geographic doubts, such as a "small Map which had reached him of the situation of the Rio Grande" captaincy. Sent by D. Pedro de Cevallos, Viceroy of Rio da Prata, "to let him see" the feel of battle in the south of Brazil, represented "only [the] Rio Grande, and [the] encampments of Brum" (José Tomaz Brum, a lieutenant from the Spanish army). ${ }^{14} \mathrm{He}$ compared all the maps seeking to confer greater precision on the frontier, but confessed that "the great work which comparing the maps has cost me", complaining that it was an inglorious tasks, since "the Portuguese maps was so small and different from the Spanish" that he did not dare "to name [to the Spanish] the places and rivers because he could go beyond the frontier line and feared to make some wrong steps" and prejudice his position.

D. Francisco complained with Aires de Sá that he did not have exact maps and even the Mapa das Cortes left "large spaces to be discovered and filled in" and seemed inexact. He said that on one of them, for "his government, he had marked the Line, which showed where the division would be." This was a new copy he had made of the original Mapa das Cortes that had been sent to him. First, "he had reduced the Ponto Maior", that is adjusted the scales, correcting it in light of his other maps, based on which he had updated the geographic features and their toponyms and inserted others. He intended that this new map would become a denominator between Portuguese and Spanish cartography, in order to construct a common starting point to facilitate and give security to negotiations. However, despite his efforts, to the contrary of what had happened in Madrid, the final text of Santo Ildefonso was not supported by any cartographic documentary base accepted by both parties (Almeida, 2009, p. 86)

Nevertheless, some maps played important roles. In one of the first meetings the new Spanish negotiator, the Count of Floridabranca (José Moñino y Redondo, 1728/1808), asked if he "could get [D. Francisco's] Map, to let him see it", to which he agreed. The Count then, "asked to let him compare it with Spanish maps." Having been warned by Aires de Sá of the danger of revealing certain secrets of the geography of Brazil to the Spanish, guaranteeing that "I never showed to the Count of Floridabranca any map which could be inconvenient, nor excite in him the fire of his extremely bright genius; I showed him [...] only those which could restore good faith, which was inseparable from the business that it was intended to conclude." 15 The map was sought to clarify the geographic doubts and in this way trace the border lines without the shadow of error, in order to be accepted by the two parties. As we will see, a certain freedom of action was expected on the part of ambassadors during negotiations, principally at a time when communication between courts was slow and costly. Kings had to trust their representatives, and "this trust means granting ambassadors significant freedom of action regarding the best way to defend the specific interests of their government, and also listening to them regarding all important decisions affecting their mission" (Magalhães, 1990 , p. 20). The Portuguese diplomats enjoyed so much freedom of action in Utrecht that at a certain moment one of them, the cout of Tarouca, presented at the negotiation table "a blank piece of paper that his master sent him to make the decision he considered appropriate to his service" (Bély, 1990, p. 501). 
However, this was not the only map on which he drew the line he believed better. On at least two Spanish maps, which he had obtained in Madrid, "he had made [...] some marks in pencil", "and for his government he had drawn the Line, which shows what the division will be." In one of these, he had done this "with my son, when he was here." 16 This operation not only shows that his father had taught D. Rodrigo about Portuguese geopolitical interests in the Americas, but also took advantage of the study of maps for this, taking into account his son's opinions. Was one of these the rare Spanish map which the young man showed Raynal? We will see.

To discover this enigma, it is necessary to reassemble the geopolitical education received by $\mathrm{D}$. Rodrigo from his father during the two periods he spent in the Portuguese legation in Madrid, before his appointment to Sardinia and his short time in Paris. The lessons he received included "knowledge of civil and military architecture, drawing", including the study of cartography, because in his diplomatic action his father had perceived "that these are extremely necessary." He first stayed there between October 1777 and March 1778, during the climax of the negotiations for the treaties of Santo Ildefonso and El Pardo, when the mediators made an effort to define the route the frontier line. Between March and October 1778 , he returned temporarily to Portugal, when he received the diplomatic appointment to Sardinia. The second visit occurred between October 1778 and the end of January 1779, on the road to Italy (Diniz Silva, 2003, I, pp. $318,68-75),{ }^{17}$ coinciding with the new intensification of diplomatic activity, related to exchanges of territories which had been agreed and which affected the frontier, especially in the south. Due to the important of these negotiations, D. Rodrigo's two visits were unequalled moments to observe his father, an experienced diplomat, in action and to take the chance to educate himself in state business, principally the geopolitical interests of Portugal in the Americas. On which Spanish maps did D. Francisco draw the line?

\section{JORGE JUAN'S MAP}

To identify the "small map which produced here and on which, just for my government, I drew the Line which showed what the division will be", as the ambassador stated, it is necessary to go back to 11 April 1777 . On this date, he had the occasion "to see, without being known, a map of all of South America, which years ago this ministry had made, [...] and which is kept in the offices of the Secretary of State." From this observation it can be understood that it was kept by the Castilian authorities in total secrecy and he does not enter into details about how he managed to see it. Everything indicates that this visit was facilitated by Grimaldi's departure from Madrid, on the $31^{\text {st }}$ of the previous month, after being removed from the position of Secretary of State (Chief Minister), and the appointment of Floridabranca, who on this date took charge of the negotiations. It seemed that the latter showed him the map, or at least where it was kept, since on 30 May, D. Francisco told the Portuguese Secretary of State Aires de Sá that during a meeting, Floridabranca had "shown me the Map of America" to show the three principal points in dispute in the south: Castilhos, Rio Grande, and Santa Catarina. By referring to it as "the Map", and not "a map", it can be understood that Aires de Sá knew to what he referred, with the only one being mentioned by them being the one he saw in the offices of the Secretary of State. ${ }^{18}$ This can be explained by the political divisions within the Spanish Court on how to resolve territorial disputes with the Portuguese. Grimaldi belonged to the so-called "Golillas" group, favorable to the return to what was agreed in Tordesillas Treaty and Aranda to the "Aragonese" who defended a more pragmatic position of a greater assignment of territories. The fall of the first was linked to the opposition that the second group, led by Aranda, made him, but Floria Branca chosen to succeed him, also belonged to the "Golillas", but adopted a more conciliatory position needed in the face of the enormous territorial demands of the Portuguese (Garcés, 2016, p. 470).

In August 1777, D. Francisco sent a map to Portugal, so that Aires de Sá could settle some geographic uncertainties since this would help to specify the borders to be established. Together with this map he sent a proposal for the frontier and, after comparing the two documents, the Secretary observed that "certainly the names of the rivers along which the frontier line will run are a little exotic, but I found them on the map printed in Madrid, which Your Excellency sent me and on which Your Excellency drew the direction of the said frontier line." Since the latter was already in Portugal in August, it can be concluded that the line was drawn before the visit of D. Francisco's son and that it returned a little while later to his hands, with it being probable that $\mathrm{D}$. Rodrigo was the bearer, since he left for Madrid in October, having met with Aires de Sá just before. ${ }^{19}$

It is known that this map was Spanish ("printed in Madrid"), detailed ("in the south all the rivers were named, albeit still in a somewhat exotic manner"), and quite precise (he used it to trace the borders which he proposed to negotiate), but was it "the map of all South America" which he had seen in the offices of the Secretary of State, small in size ("the small map"), and which "years ago he had ordered made in this ministry, which as much as I could see in a short time, was based on the Memórias of D. Jorge Juan"? Here he is referring to the map which the military engineer Jorge Juan (1713-1773), produced to accompany the first Spanish edition of Disertación Histórica y Geográfica sobre el Meridiano de Demarcación entre los Dominios de España y Portugal, written with Antonio de Ulloa (1716-1795), which was published in 1749 in Madrid (Juan and Ulloa, 1749). However, this work and its enclosed map, around 250 to 300 copies of which were printed, did not circulate then since it was immediately impounded at the order of the Spanish Crown. ${ }^{20}$

The reason for the confiscation, according to the Marquis of Grimaldi, was that the plates were "badly marked and to correct some slight mistakes" (Gómez, 1995, pp. 
1586-1588, n. 78), which explains one of its rare remnants being kept, in all secrecy in the offices of the Secretary of State, since "examples were only sent to the ambassadors who resided in the in the Courts of Europe." Despite what the Marquis explained, it was not just any error. D. Francisco states that the map "contains two parallel lines, drawn according to the Treaty of Tordesillas; one which begins in the Island of São Nicolau in Cape Verde and ends in Cabo Frio; another which begins in the Island of Santo Antão, also in Cape Verde, and ends in the captaincy of São Vicente." ${ }^{21} 1749$, the year of its publication, coincided with the intensification Luso-Castilian negotiations, resulting in the Treaty of Madrid. The island of Cape Verde which had served as a reference for the Tordesillas meridian had determinant impact on what both parties negotiated, especially in the south of Brazil, while Spain defended a line more to the east (São Nicolau island) and Portugal more to the west (Santo Antão). The two positions drawn on Jorge Juan's map differed from what was argued in Disertación Histórica y Geográfica: both cut across the captaincy of São Vicente —one in the island of São Sebastião and the other in the mouth of the Itamán River. This also clashed with the understanding of the Portuguese, for whom the line left Brazilian territory much more to the southwest, expanding the territory under their dominion. For one reason or another, the error was determinant for the impounding of the edition, since for the Spanish the climate of animosity that such a map could cause was of no interest.

However, more than discussing these positions, it is interesting to discover if the map on which D. Francisco drew the line was Jorge Juan's map of South America. This can be determined based on various pieces of evidence: both show the entire continent of South America; the place of publication is the same, Madrid; they are fruits of the initiative of the Secretary of State and served at the time to resolve the question of borders. In relation to their printing dates, the former was old, ("years ago this ministry ordered it made"), it was thus made before 1772 , since, according to D. Francisco, those of that year were imprecise ("they are worth nothing") and after this date, "they have not made others except for the large one I already sent to Your Excellency and you returned", referring to the other map he had sent in 1778, and which will be dealt with below. Jorge Juan's Spanish original, from

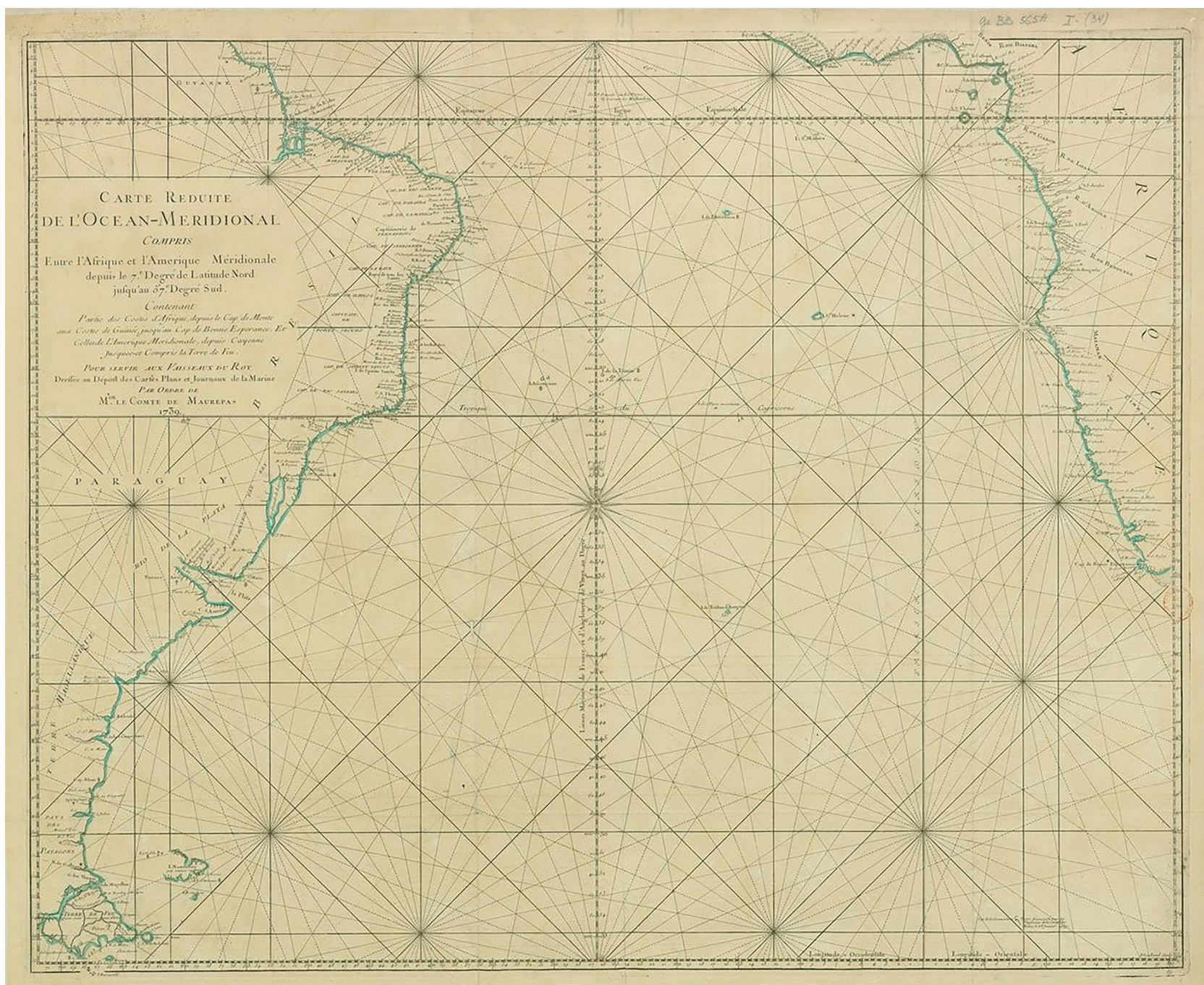

FIgure 7. Carte Reduite de l'Ocean Meridional Compris entre l'Afrique et l'Amerique Méridionale, 1739. BNF, DCP, IFN-5905777. 
1749, also fits this chronology. Finally, the map was sent to Portugal occurred during the discussion with Aires de Sá about the pertinence or not of the lines which Jorge Juan had imprinted on the Tordesillas meridian, which Spain insisted on using as the defining line. Sending it to Lisbon allowed the Secretary to see this, as well as the line with the ambassador proposed. D. Francisco had heard talk for the first time of the existence of this edition, which was kept in the basement of the office of the Secretary of State, in a meeting with the French ambassador in Madrid, on 22 June $1776 .{ }^{22}$ Certainly this piqued his curiosity, until he final managed to see it in April of the next year.

Unfortunately, the rare remaining examples of Juan and Ulloa's book contain only the textual part, such as the one from the library of the Viscount of Balsemão (Costa, 2000 , p. 70 , n. 1$),{ }^{23}$ with no 1749 original being located, but it is possible to have an idea of its configuration, since two base maps were used to produce it. The first, considered reliable, was Carte Reduite de l'Ocean Meridional Compris entre l'Afrique et l'Amerique Méridionale (Fig. 7), from 1739 and published in 1742, at the order of the Count of Maurepas, for the use of the French navy, "and which was made using astronomical measurements and reliable and contrasting references obtained from various courses of ships." ${ }^{24}$ As it was limited to the State of Brazil (the east part confined between Tordesillas line and the Atlantic Ocean), to represent Grão-Pará and Maranhão, on the west of Tordesilhas Line, they used the map of the

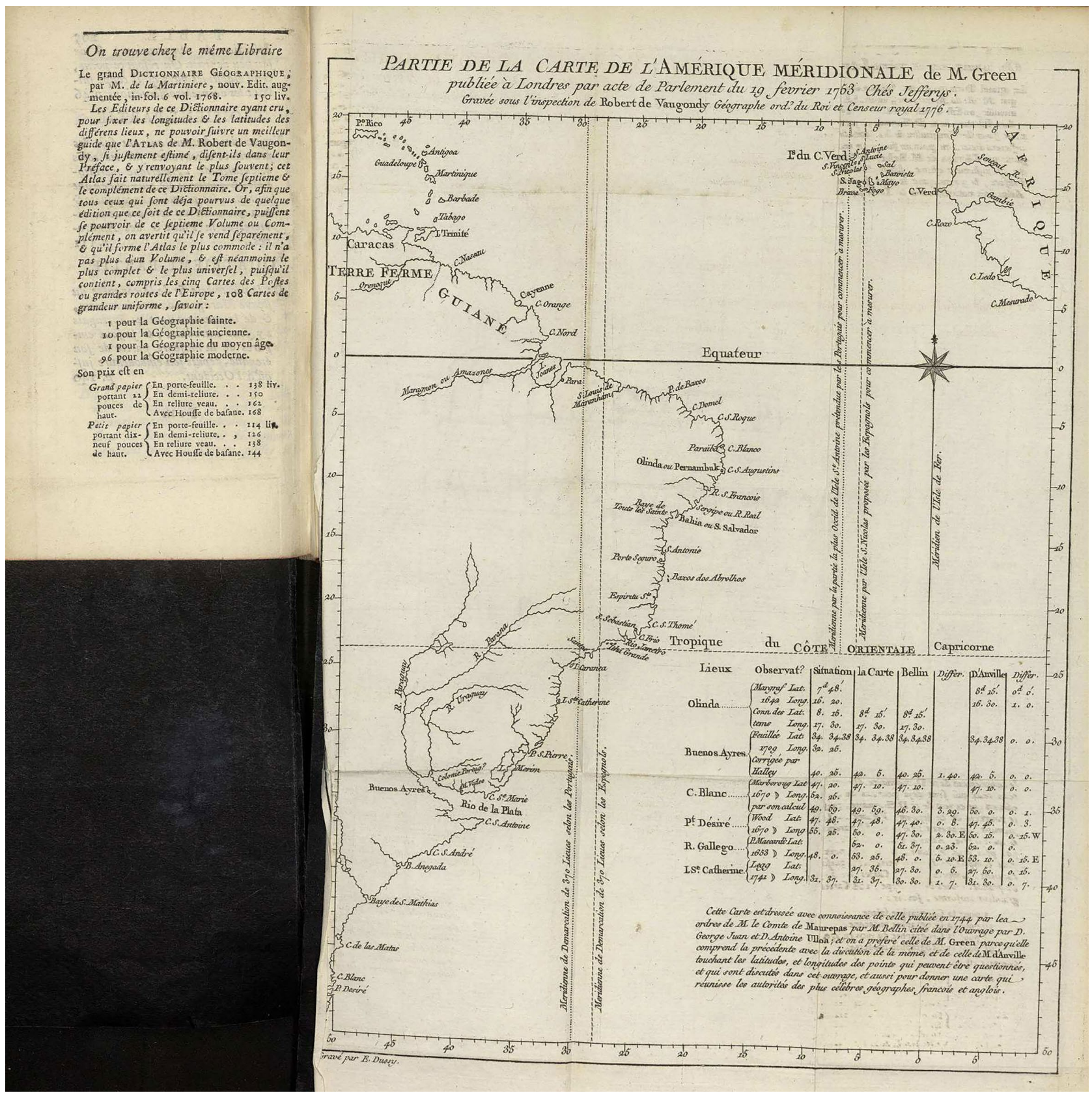

FIGURE 8. Vaugondy's version of Jorge Juan's Amerique Méridionale, 1776. BNE, GMM/2055, bdh0000001405. 
River Amazon, or Maranhão —as the Portuguese called the lower part of the river-, by La Condamine (Fig. 4) (Gómez, 1995, pp. 1578-1579).

Another version of the 1749 map exists, produced in 1776 to accompany the new edition of Juan and Ulloa's book printed in France (Fig. 8). Although it had been made at the order of the Spanish crown, it can be excluded as the one on which D. Francisco drew his lines since it was French and recent as it was only recently made. It was produced under the supervision of the French geographer, Didier Robert de Vaugondy (1723-1786) who to show his precision, compared in the cartouche the position of various locations on the coast of Brazil and Buenos Aires, according to the maps of Bellin (1744), d'Anville (1749), and the English cartographer John Green (1753). Vaugondy used the original of the latter, ${ }^{25}$ which he considered the most precise, as the base map, but reduced it to a much more schematic form, deleting most of the geographic features of the interior, including rivers and their toponyms, which Aires de Sá observed had appeared in detail on the map on which the ambassador had drawn his line. A further reason to exclude it. On the map of Brazil two positions were drawn for the Tordesillas meridian, this time corresponding to what was defended in the text. In the south, both left Brazilian territory in São Paulo and written above them was respectively the position of the Spanish and the Portuguese, although this was not entirely true.

By reprinting Juan and Ulloa's map in France, both members of the British Royal Society and the Académie de Sciences de Paris, this time under the supervision of a French geographer, all respected in savant circles, and choosing as the matrix a map from England, traditional ally of Portugal, the Castilian Crown sought to transmit exemption and legitimate its territorial pretension before a European audience. When the negotiations actually began in Santo Ildefonso in 1777 its position was to stick to what had been stipulated in Tordesillas, as Juan and Ulloa advocated in their work, without ceding any territory to the Portuguese. In turn, Portugal defended maintaining what was established in Madrid, considered a much more favorable treaty (Gómez, 1995, pp. 1561-1592). For D. Francisco, who already knew the first and second maps, the four positions of the line amounted to a sophism, ${ }^{26}$ in other words, produced with the aim of deceit and hiding the truth, in an apparently logical form, but deliberately incorrect and misleading. The discourse of maintaining the Tordesillas meridian sought to undo this in the negotiations with the Spanish and in the collaboration of him and his son with Raynal, giving visibility to the fairness of the Portuguese pretensions by constructing a geographic counter-discourse, based on what was agreed in the Treaty of Madrid.

It should be noted that when he drew the frontier line on the Spanish map, D. Francisco already possessed the new French edition. In January 1777, he sent one of his copies to D. Rodrigo in Lisbon, confessing that "since last year I have had the works of D. Jorge Juan to send to you" (Diniz Silva, 2003, I, p. 321). His purpose was that his son would educate himself in the fron- tier disputes of the Americas. Perhaps D. Francisco had obtained the book from his twin brother, D. Vicente de Sousa Coutinho (1726-1792), ambassador in Paris, as soon as it was printed, or when it reached the book market in Madrid. ${ }^{27}$

Referring to the map from the first edition, Aires de Sá commented that in relation to "the parallel lines which Your Excellency saw on this geographic map, there is not the slightest doubt that, taken as the Spanish mathematicians intend (...), they cut the globe very differently from what would be done by today's mathematicians, and that these and even D. Jorge Juan, who was very intelligent, could not fix them precisely due to the uncertainties of longitudes." For him, the most recent maps, such as the 1776 edition, produced by more modern cartographic methods, were more exact. D. Francisco, in turn, preferred the older one, considering it a better geographic representation of geography, especially the hydrographic network of the south of Brazil, which was the principal natural demarcation of the terrain, and Aires de Sá recognized this merit. ${ }^{28}$

\section{CRUZ CANO'S MAP}

The second time that D. Francisco used a Spanish map with the purpose of drawing a frontier line occurred when D. Rodrigo was already temporally back in the Portuguese ambassy in Madrid, since as he says, "the argument on which this map is based is certain, a map on which I made some pencil marks with my son, when he was here." This map was sent to Portugal, in May 1778, when he and Floridabranca tried once again in Madrid to settle the frontier. The intention was that in Lisbon, consulting his geographers, Aires de Sá could see the map and its line, "to examine it easier" and resolve the "doubts which existed about the Igurei and Correntes rivers," 29 situated in the South of Brazil, which served as the frontiers in accordance with Article VI of the Treaty of Madrid. Also so that the secretary could "compare it with those [maps] there and remove any doubts, or with the names of river, or with others found at the same height and which should replace them; [and] they could argue with maps which are not known here." He also asked that any other points be clarified and it be returned quickly, which was answered that "I will return it with the most possible brevity after having made on it the observations which Your Excellency noted." 30

The ambassador stated that he had had that map "for a long time", keeping it in his power, because "there would always been the need to examine it" during the negotiations between 1776 and 1778 . He does not provide information about its title, nor who made it, only that it was the "large Map of America which was made here a few years ago because of our questions; so that Your Excellency could compare them with those that were there and resolve any doubts." From these initial observations it can be concluded that this does not involve Jorge Juan's older map of a smaller size which he had sent the previous year. He also reveals "that the map is not mine because it 
has not been published here, a man lent it to me [...] and I did not return it to him." This mysterious individual is not identified, because there was always the risk that his correspondence would be intercepted on the road and his Madrid informants discovered by the Spanish, since a certain amount of espionage was inherent to diplomacy (Bély, 1990; Furtado, 2012). When he was in Aranjuez and the map in Lisbon, he told Aires de Sá that "four days ago [its owner] asked me" to return it, but he managed to delay this as the map was in Lisbon with the excuse "that I could only do this when I went to Madrid, because it was in part [of the house] which only I entered." He recommended that "it is necessary for Your Excellency to have whatever is necessary copied to send it to me, or order that the man be asked about its sale, with whatever whims he has, due to its rarity and the impossibility of getting another." $\mathrm{He}$ reassured him that there would be enough time to return it, "until the Man pursues me, because he will not press me so much that it will not allow eight days delay." 31

The clues he provides about the map he had sent to Lisbon in 1778, on which he drew a new frontier line, allow it be concluded that it is Mapa Geográfico de América Meridional by Juan de la Cruz Cano y Olmedilla. Both are of a similar size: the former was "a map of the Americas" or "a large map of the Americas" while the latter is a mural map, made by 8 sheets, measuring $2.63 \times 1.83 \mathrm{~m}$ and representing the entire continent. Both resulted from the patronage of the Spanish Crown, serving its negotiations with Portugal although never formally presented. The date of production, the prohibition of circulation, and rarity also coincide: the former "was made here a few years ago because of our questions", though "they have not published it here", hence the "impossibility of having another;" while the four Spanish editions of Cruz Cano, printed in the interval between 1775 and c. 1777, were immediately impounded, according to Grimaldi "it was made here and its sale is not permitted", and until 1802 its circulation was prohibited, which makes its copies very rare (Donoso, 1963; Smith, 1966; Almeida, 2009, pp. 8386; Mitchell, 1999, pp. 6-11; Garcés, 2016).

Like Jorge Juan's map, Cruz Cano's one had a troublesome existence (Donoso, 1963; Smith, 1966, pp. 4977). The first proof edition, from the end of 1775 (Fig. 9), ${ }^{32}$ was impounded at the order of Grimaldi, who considered its frontier lines unfavorable to the Castilians, since Spain defended the maintenance of the Tordesillas meridian (Smith, 1966; Almeida, 2009, pp. 83-86), as Juan and Ulloa postulated, and roughly speaking the map mirrored what was negotiated in Madrid. ${ }^{33}$ An exception is the Orinoco region, whose frontiers was to be formed by a "Mountain range", situated between this river and the Amazon, but the map situates it on the course of the Branco River. Another is found in the south, where there are two frontier lines, both straight, one in orange and the other in pink, running in a north-south direction. The first, more to the West, reflected the Portuguese interests in exclusive dominion over Lake Mirim; the second, to the east, was favorable to the Spanish, but did not correspond to what was negotiated in 1750 .
The second edition, from February 1776 (Fig. 10), with differences from the 1775 's proofs, ${ }^{34}$ was printed with a limited number of copies, only for the use of those responsible for the negotiations then beginning, such as Grimaldi himself, the Count of Aranda (Pedro Pablo Abarca de Bolea, 1719-1798), ambassador in Paris, and the five member Junta which met from June 1776 onwards to prepare the Spanish position: Pedro Cevallos; the Marquis of Valdelirios, who had been in charge of 1750 Southern demarcation commission; D. Antonio Porlier, an Auditor from the Council of the Indies; Brigadier D. Vicente Doz, from the Orinoco border commission; and D. Francisco Arguedas, a former commissaire from the Southern demarcation commission (Donoso, 1963, pp. 127-129; Ramos Perez, 1974, p. 28; Tapia, 1995, pp. 1669-1670; Garcés, 2016, pp. 479, 496-497). Only seven examples were printed, ${ }^{35}$ which together with the following editions (the third is estimated as occurring between July and December of 1776 and the fourth in 1777), were all kept by the Secretary of State, with its sale having been forbidden, since according to Floridabranca, "it is not permitted to sell the map of South America made here due to its errors" (Donoso, 1963, p. 122) From the second edition onwards the frontier line was removed from the copper plate by order of Grimaldi, allowing privileged readers to focus on the map geography, experimenting various lines (Donoso, 1963, p. 123; Garcés, 2016, p. 505) In 1789, there were 151 maps remaining in storage (Almeida, 2009, pp. 8587).

At first, Grimaldi order Cruz Cano only to copy the General Map of South America, by Francisco Millau y Maravall. But he convinced Grimaldi to start drawing a new map in 1767 , based first on sixty-two maps, charts and probably manuscripts coming from the Archives of the Indies with various origins (Smith, 1966, pp. 56-57). Latter his sources enlarged, including Jesuit cartography (Garcés, 2016, pp. 222-320). Although there were important variations, the first edition was based on Mapa das Cortes and, as could be expected, Spanish possessions were more exact and detailed that the Portuguese part, except for the Amazon basin and the south of Brazil, based on the cartography produced by Spanish parties after the post-1750 demarcation (Almeida, 2009, pp. 85-86).

From Bonne's information, it is known that the "beautiful Spanish Map by M. la Crux", which was "very good", "excellent" (Bonne, 1780, pp. 13-15), served as the basis for the production of the seven maps of South America in the Atlas, and was given to him by Raynal. In turn, D. Rodrigo says that he showed the Abbé the "«famous and very rare» [map] of Spanish America which he owned" (Diniz Silva, 2006, II, pp. 99, n. 4). This copy “did not yet contain the frontiers and was not even published" (Bonne, 1780, pp. 13 and 15), which, together with the information that D. Francisco had possessed it for a long time, allows it be identified as from the second or at most the third edition. As can be seen the ambassador had excellent connections in Court and the mysterious Man can be reduced to no more than seven central individuals from the Spanish administration. Some can be excluded as they 
a)

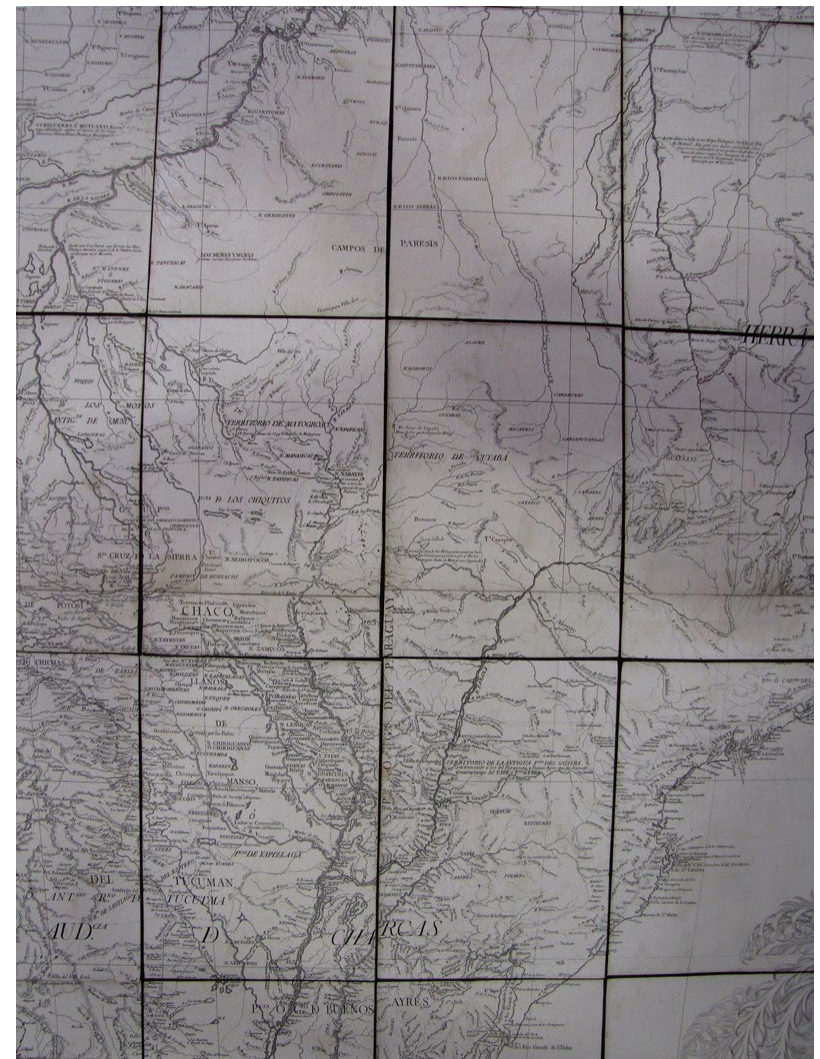

d)

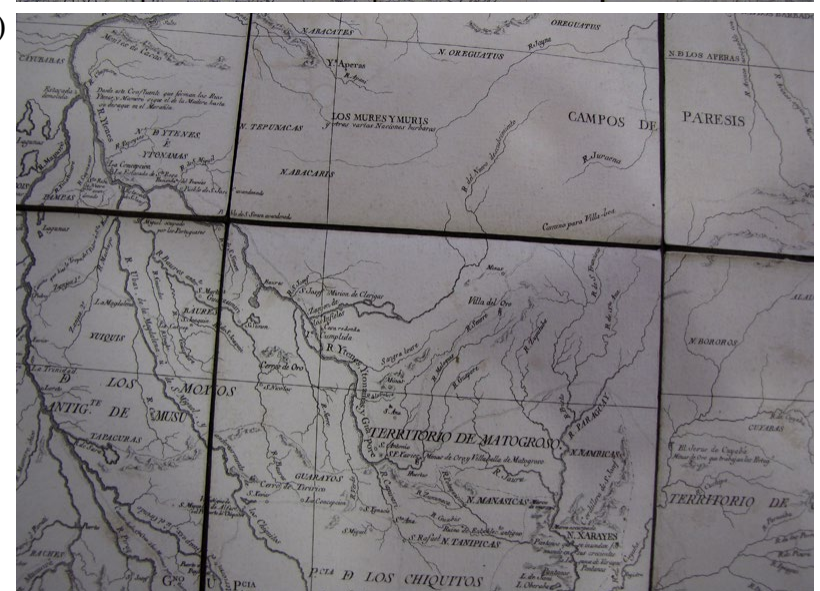

f)

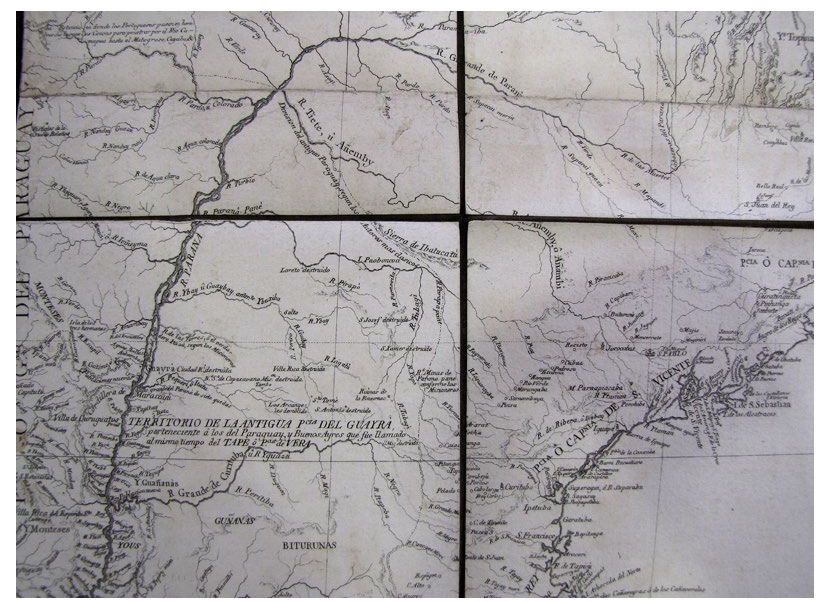

b)

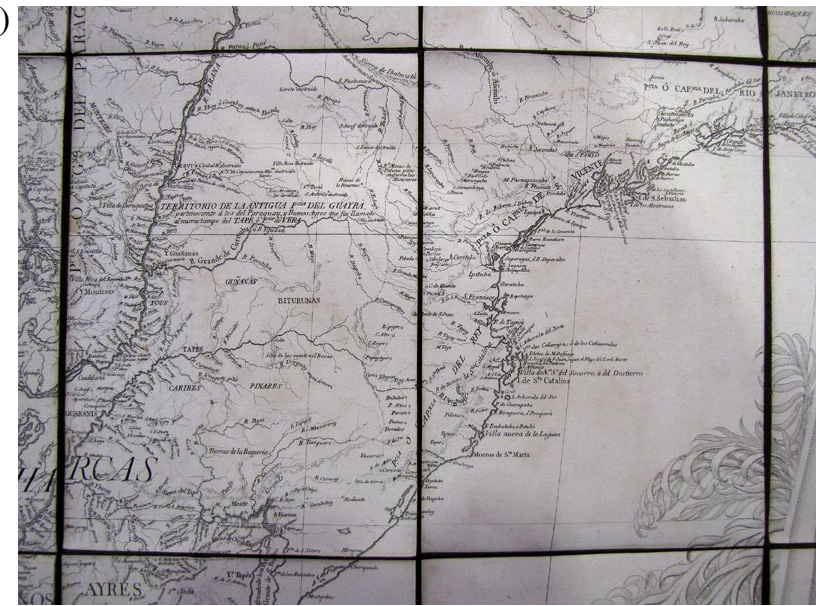

c)

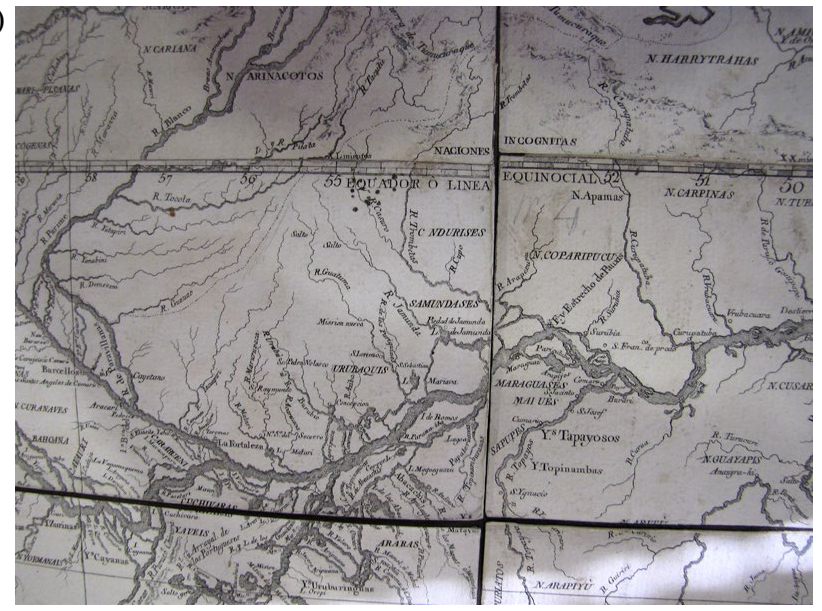

e)

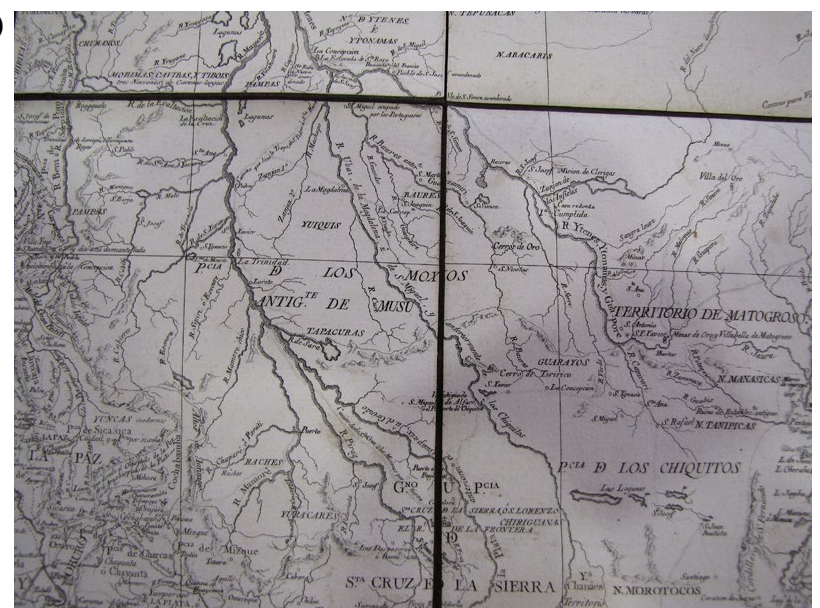

Figure 9. Details of Juan de la Cruz Cano y Olmedilla, Mapa Geográfico de América Meridional, 1775 (rare example of first edition). Newberry Library, Ayer Collection. (a) Boundary line between the Portuguese and Spanish possessions; (b) South detail; (c) South, center and West; (d) Center, West and North; (e) North; (f) Northern end. 

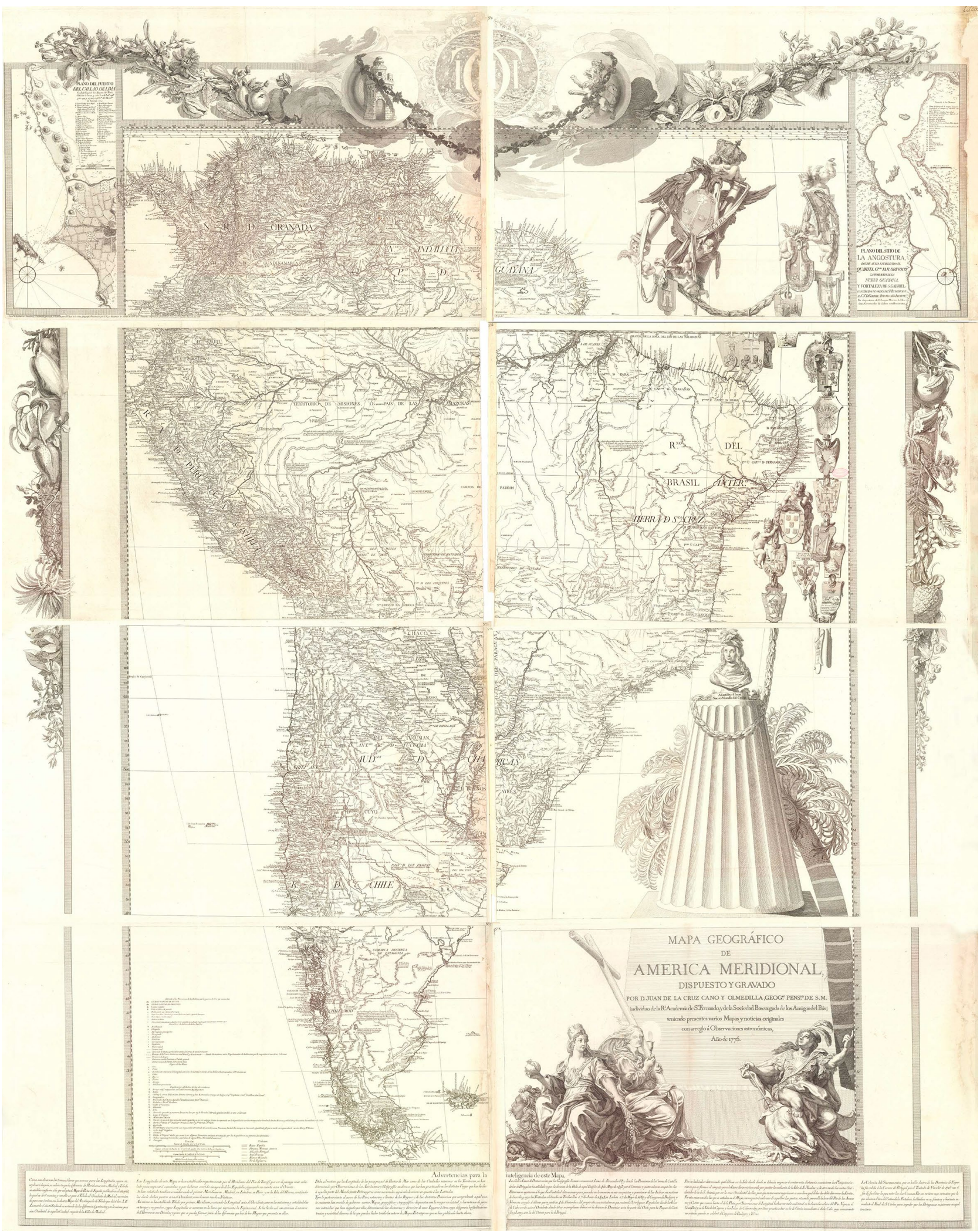

Figure io. Juan de la Cruz Cano y Olmedilla, Mapa Geográfico de América Meridional, 1776. 
were not in Madrid, such as Aranda, who remained in his post in Paris, and Cevallos, who left in November 1776, to lead the Spanish enterprise in the South of Brazil, bringing with him his map (Tapia, 1995, p. 1682); or because they were not part of his circle, such as the Marquis of Valdelirios, whom he did not know, "not even by sight." 36 Despite all the care of the authorities to keep it secret, he not only managed to get hold of one of the very rare printed copies, but with his son drew on it the frontier line he considered of interest to the Luso-Brazilians. In showing the map to Raynal, an inverse cartographic strategy to what the Spanish had followed with Jorge Juan's map can be observed: this time it is a Portuguese who uses a Spanish map to influence French and, by extension, European public opinion, submitting the maps of the Atlas da Histoire des deux Indes to Portuguese geopolitical interests.

In his analysis of the documentation referring to the negotiations of Santo Ildefonso, André Ferrand de Almedia did not find "any references to this [by Cruz Cano] made by Portuguese negotiators" and asked if "they had actually seen the map before signing the treaty?" (Almeida, 2009, pp. 85-86) and more recently José Andrés Jimenés Garcés sustained that due to the Portuguese territorial occupation represented in the map, Spain never showed their representatives the map (Garcés, 2016, pp. 515-516). However, D. Francisco's affirmations that he had had the map "for some time", keeping it in his power, because "there will always be a need to examine it" during the negotiations, and only sending it to Portugal in 1778, after the signing of the Treaty of El Pardo, unequivocally reveals that they had. How did his map end up in the hands of D. Rodrigo in Paris?

First the map returned to Madrid ("I have sent it to [Aires de Sá] and he sent it back to me"), however, instead of giving it back to its owner, D. Francisco managed to keep it with him, although he warned that the map was "extremely rare and, without the Minister having given it to him, he could have not got it in any way." He was referring to Floridabranca. Can it be inferred that the latter gave to him directly, or at least gave the order that he could acquire it? What is certain is that it was in his possession and shortly afterwards when the Secretary asked for it again, he apologized saying that "I will ask or ensure that my Son, who brought me the one that I had, send it to Your Excellency." This statement confirms that the map which D. Rodrigo brought to Paris was undoubtedly that of Cruz Cano. When his son told him that he had shown it the Abbé, he reassured him, saying that providing Raynal with correct information was "an occasion to preserve our rights", since "the reports they have of Brazil are certainly not very secure [...]; since no foreigner knows anything profound about our conquests, forces, and trade" (Diniz Silva, 2003, I, p. 335). But how were the lines drawn on the maps of Jorge Juan and Cruz Cano configured?

\section{THE GEOPOLITICAL VISION OF THE AMBAS- SADOR IN MADRID}

For D. Francisco, Brazil ran from the Amazon to the River Plate, but during the 1777-1778 negotiations he was more concerned in defining its southern limits, which he considered threatened by recent Spanish invasions. He agreed with Floridabranca that the principal differences there were related to Castilhos Point (Ponta de Castilhos), the captaincy of Rio Grande, and the island of Santa Catarina. His idea was that on the coast the frontier would start at Castilhos, "or a little removed from it", as defined in Madrid. However, he confessed that this was not in the Spanish interests, promising to obliterate "all the efforts" to establish it closer to the banks of the River Plate. His wish was for São Miguel fort, built by the Portuguese on the Southern shore of Lake Mirim, alongside a small river with the same name, to remain under Portuguese dominion. ${ }^{37}$ However, he was unsuccessful. In Santo Ildefonso, the frontier line was established a little more to the north, with the Chuí River being the dividing line in the internal part of Lake Mirim, navigation on which would be shared, and Castilhos Point staying on the Spanish side. The strip of land between the sea, this lake, and Lake Patos would be of common usage.

For him, west of Lake Mirim the frontier line should "run as straight as possible", to the source of the Negro River, and there to turn northwest, reaching the sources of the Ibicuímirim. Next it would follow the Ibicuí River westwards until the Uruguay River, following its courses until the mouth of the São João River, "using the straightest line permitted by the situation of the terrain", guaranteeing Portugal the east bank of the Uruguay River, where the Jesuit Sete Povos das Missões was located. It should then turn northwest, following its tributary Pipiri, until it reached the Paraná River, maintaining exclusive navigation on the São Pedro, Guaíba, Jacuí, and Pardo rivers, all located in the captaincy of Rio Grande, considered fundamental for Portuguese dominion in this region, removing the Spanish presence there. He was not completely successful, Santo Ildefonso ceded the region between the Ibicuí and Uruguay rivers to the Spanish, including Sete Povos das Missões.

In relation to the River Plate region, he was favorable to the surrendering of Sacramento Colony, since he considered the cost of maintaining it high and risky. This loss would be compensated with the gain resulting from the "fine pasture" of the captaincy of Rio Grande, where extensive cattle raising flourished, a vision he had expressed since January 1776, when he had written, at the request of the Marquis of Pombal, a Memorial, which he sent to Grimaldi, about the territorial equivalent which could be negotiated with Spain. In this document, the "equivalent of Sacramento Colony" was Sete Povos da Missão and a significant part of the Northern bank of the River Plate. As diplomats have some freedom to act, his proposal did not correspond with the wishes of Pombal, who complained with him for having sent it to Grimaldi, who could use it as the basis for negotiations, as happened at the beginning. After the military attack of the Spanish on the south of Brazil, he argued that what was important was to "guarantee the restitution of Santa Catarina island and maintain exclusive dominion over Rio Grande captaincy, due to contraband." He had a paradisiacal view of the island, 
due to the description made of it by a certain "Brigadier Salazar, who found himself in that conquest, having seen all of Europe, had never found such a delightful and so comfortable port like that one [...], since no place on Earth seemed better." He defended that "the means of securing it should be competed for" and he was successful: Santa Catarina and Rio Grande remained with the Portuguese. ${ }^{38}$

In the center-west, it was fundamental to guarantee the exclusivity of navigation on the Jauru River and traffic on the road between Cuiabá and Mato Grosso, called the Monções, as stipulated in Article VIII in the Treaty of Madrid. The former allowed the connection with the North and the latter with the Southeast, through which flowed the gold extracted from there. Following this the frontier line followed the Paraná River northwards until it reached Pantanal or Xarais Lake. The passage between the Paraná and Paraguay rivers was one of the most imprecise points on the line. Article VI of the Treaty of Madrid defined that it would follow a river, "perhaps it will be the one called Corrientes", and D. Francisco kept this configuration in Santo Ildefonso (Article IX). Then the frontier line headed northwest along the bed of the Jauru River and then the Guaporé, cut across the Madeira and Amazon rivers at the confluence with the Javari River — the most westerly

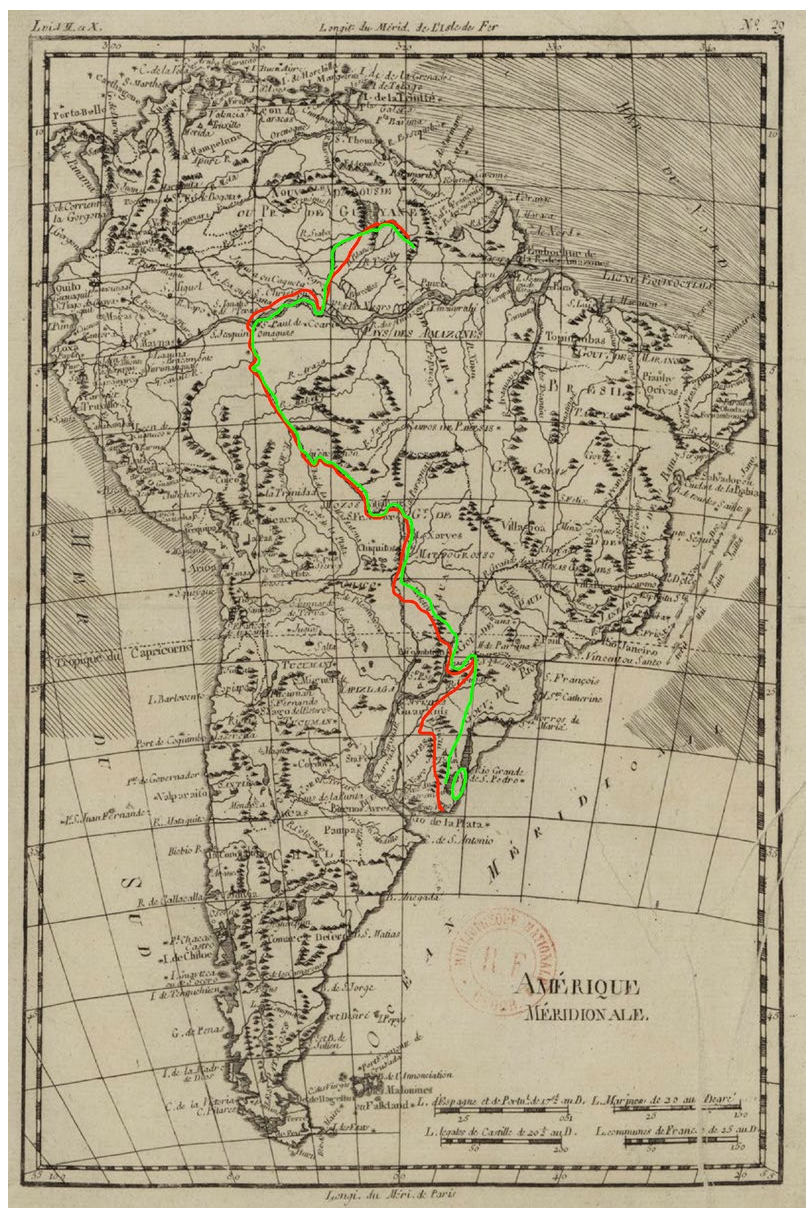

FiguRE I I. Lines of Madrid (red) and Santo Ildefonso (green) over Bonne and Raynal's Amerique Méridionale, 1780. BNF, DCP, H.G.22484v. point - and on the northern bank of the Amazon River reached the Negro River. In this manner, "the provinces of Charcas and Maynas; as well as all of the Orinoco" were ceded, as stipulated "in the 1750 Treaty." For visualization, the frontier line proposed by the Treaties of Tordesillas and Santo Ildefonso (Fig. 11) and the one preferred by D. Francisco were drawn on the map of South America in the Atlas (Fig. 12).

However, when the copy of Cruz Cano's map reached Portugal and Aires de Sá saw "the Line, which I had drawn in pencil on the map and just for my government", he advised that "it would be useful to move it away from the capital of Mato Grosso", since it was necessary to guarantee possession of Vila Bela, located neared Guaporé River and in fact this was ratified in Santo Ildefonso. $\mathrm{He}$ also warned that "the line running from the Amazon River towards the Madeira River seemed to me to be nearer the source than it should be; for the reason of freeing the necessary navigation from Mato Grosso to Pará captaincies, along the Aporé, Mamoré, Madeira, and Amazon rivers." D. Francisco justified these mistakes, saying "that, in first place, the said imaginary line was drawn along the rivers named in the Treaty [of Madrid], and which I cannot know if in the said map [by Cruz Cano] they are these,

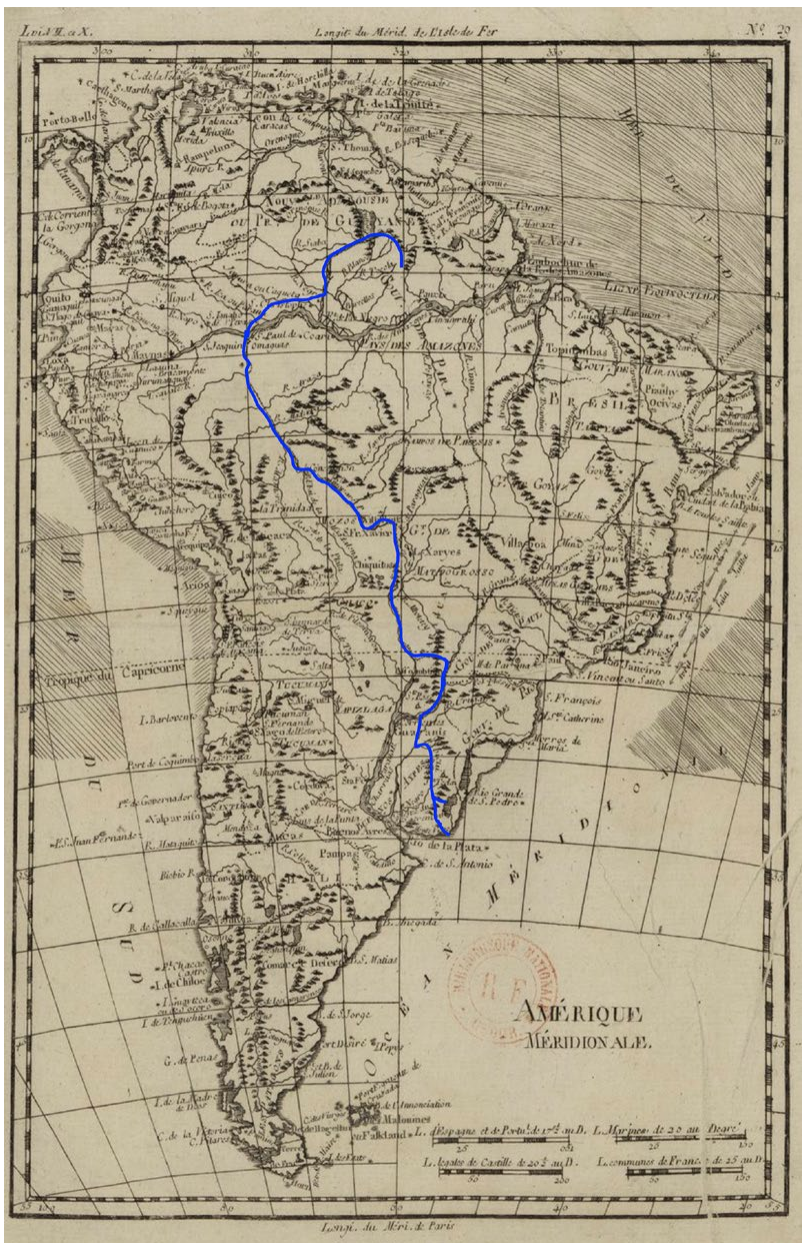

FiguRE I2. D. Francisco's favorite line (blue) over Bonne and Raynal's Amerique Méridionale, 1780. BNF, DCP, H.G.22484v. 
like the said capital, well located" and went about correcting it. ${ }^{39}$ Roughly this is the line D. Francisco draw on the Cruz Cano map showed to Raynal. However, it was not only him who tried to influence the Abbé about the borders of Brazil. The Viscount of Balsemão also provided him with geographic information.

\section{THE FRONTIER IN BALSEMÃO'S MÉMOIRES}

Although he was a collector of maps, and having been involved in the production of various when he was Governor of Mato Grosso (Garcia, 2011; Coutinho, 2009; Costa, 2012, pp. 140 and 148; Rodrigues, 2020, p. 317), Balsemão did not send a map to the Abbé but rather, as stated, two textual documents: although the Mémoires were numbered I and the Extrait II, determining their order of reading, everything indicates, however, that Balsemão finished the Mémoires last. The 1778 Treaty of El Pardo is mentioned in it, while the Extrait describes the "Geographic division of Brazil and the other possession of the Portuguese Monarchy in South America according to the current state of its conquests in 1777", based on the ambassador's understanding and, in part, in disagreement with what was being negotiated in Santo Ildefonso. ${ }^{40}$ The two documents were sent to Raynal after 2 May 1778, when the orders from the Portuguese court arrived allowing him to answer Raynal's questionnaire on Brazil (Furtado and Monteiro, 2019, p. 17).

The Mémoires deal with the theme of frontiers, narrating the Luso-Castilian negotiations. Its narrative sustained the position that the treaties negotiated by the Portuguese from 1680 was imposed on what had been agreed the Tordesillas, the meridian to which the Spanish still held. Balsemão ends with what was his "projet favori", which would end once and for all these disputes. Daringly, out of tune with what the Portuguese advocated, he proposed to give up the entire northern bank of the Amazon, from the Napo River to the Madeira River, giving up exclusive navigation rights on this extensive western part of the Amazon river in exchange for the northern bank of the River Plate and the eastern bank of the Paraguay River -hypotheses never suggested by Portugal.

In fact Extrait des Notes details the frontier of Brazil in accordance with his "projet favori." This is a mental map, produced so that Raynal and Bonne could confer a cartographic feature on written geography. At the beginning, he warns them that "foreign geographers believed that the Western frontiers [of Brazil] are undefined, but they are mistaken." He promised to show them "how the Portuguese recognize them", but his description did not coincide with what the Crown negotiated in Santo Ildefonso but rather as his own vision of the geopolitics of Brazil. ${ }^{41}$ He sustained that as defined in Tordesillas, the keys were in the Amazon River in the north; in the south and center-west the River Plate, which flowed into the Paraguay, and in the east, the Atlantic Ocean. But his understanding of River Plate is much larger, comprising its interconnected basin in the west. Roughly speaking, in the north it guaranteed an extensive territory, covering the northern bank of the Amazon River, Vicente Pinzón Bay, and the mouth of the Javari River, but gave up the Amazon southern bank between the latter and the confluence of the Madeira River. In the center-west, what had been negotiated in Madrid was to be expanded, annexing part of the province of Paraguay, below the Tropic of Capricorn, resulting from his experience as governor of Mato Grosso, which led him to valorize the region. In the South, the line excluded Sete Povos das Missões, but covered Sacramento Colony and Lake Mirim, with the frontier line running to Santa Marta Cape, at the mouth of the River Plate.

From Vicente Pinzón Bay, the extreme northern point, located at $4^{\circ}$ latitude, the line continued west in an imprecise form, since it did not detail the geography which served as a reference, until it reached the Cassiguary canal, the fluvial communication between the Negro and Orinoco rivers. From this point, it goes towards the Ixié River, which flows into the Negro, heads towards the source of the Issanã and, afterwards the Apepuri River, which runs into the Japurá River, when it curves to the south, cuts across the Issa and the Amazon rivers, and goes to the mouth of the Javari River, the most western Portuguese point. Here was the most controversial point of the proposal: the frontier line turned east, following the bed of the Amazon River, until it reached the mouth of the Madeira, located at a longitude of $311^{\circ}$ West (measured from the Ferros meridian). This signified that the entire Southern bank of this part of the Amazon, the Missions region, would remain with the Spanish and navigation on the river would be shared.

After this the line turns towards southwest, following the bed of the Madeira until Mamoré River and from there to Guaporé River until reach Vila Bela, located at $15^{\circ}$ latitude and $318^{\circ} 45^{\prime}$ longitude, with the Western province of Chiquitos remaining on the Spanish side. From this point, it runs south along the Guaporé River, enters the Alegre stream until the Jauru River, following this until its junction with the Paraguay River, going southwards along its bed. In this vast section, between the confluence of the Madeira-Mamoré and the Paraguay, Balsemão remained tied to what had been agreed in Madrid, but from here he proposed a new controversial conformation: the frontier line runs along the channel of the latter until the confluence with the Ipaniguaçu River, located below the Tropic of Capricorn, when it turned east, following its bed and running until the Iguatemi River, until it flowed into the Paraná River - territory belonging to Paraguay, never claimed by the Portuguese. From Paraná River, once again heading in a southern direction, it goes to the mouth of the Iguaçu, following its bed northwards, until it reached the source of the Uruguay River. This route moved the frontier much closer to the coast, once again going against what the Crown proposed. In this point, where "the demarcation between the two empires is almost undefined", the line goes almost straight southwards, following the Jacuy River, reaching the mouth of the Ibicuí and the Negro River, ending in Santa Maria Cape, southeast of Lake Mirim. Discontinuous from this territory, "Portugal also holds at the edge of Brazil, Sacramento Colony on the Northern 
bank of the River Plate", guaranteed in exchange for the territory ceded in the Amazon. ${ }^{42}$

For visualization, the line proposed by Balsemão was projected on the map of South America in the Atlas (Fig. 13). Although it was very controversial from the point of view of the Crown in Lisbon, the ambassador did not shy away from trying to influence the Abbé with this particular vision of the Brazilian frontiers! Were Raynal and Bonne passive readers of information, at times contradictory of each other, passed on by him and D. Francisco?

\section{CONCLUSION: THE LIMITS OF SOUTH AMERI- CA IN RAYNAL'S ATLAS}

Despite the two diplomats, generally speaking the frontier of Brazil drawn on the map of South America in the Atlas (Figs. 6 and 14) reflects what was agreed in Santo Ildefonso and El Pardo by D. Francisco. However, there are exceptions and almost always they are due to Balsemão. In relation to the regions which remained undefined, what was established in Madrid is followed, as both advocated. There were also occasional discrepancies in the Southern region and in the North Cape, disputed with the French.

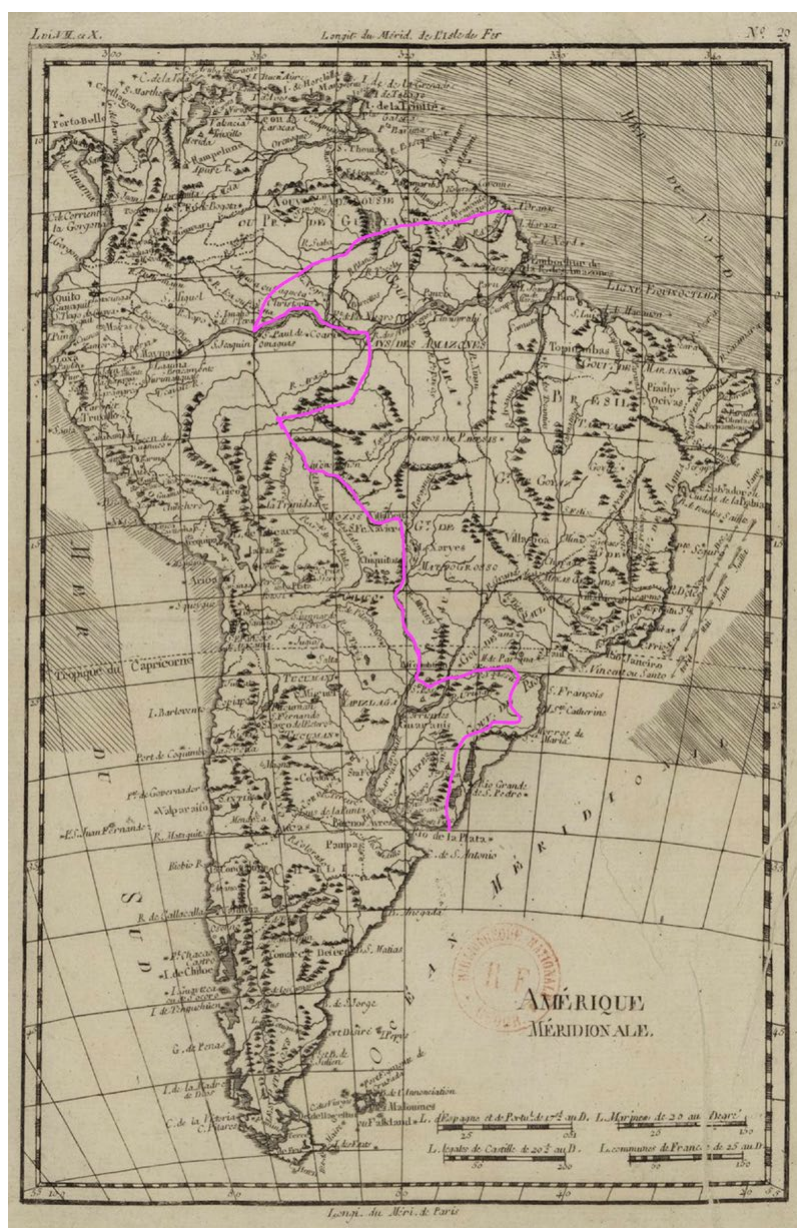

FIGURE I3. Balsemão favorite line (pink) over Bonne and Raynal's Amerique Méridionale, 1780. BNF, DCP, H.G.22484v.
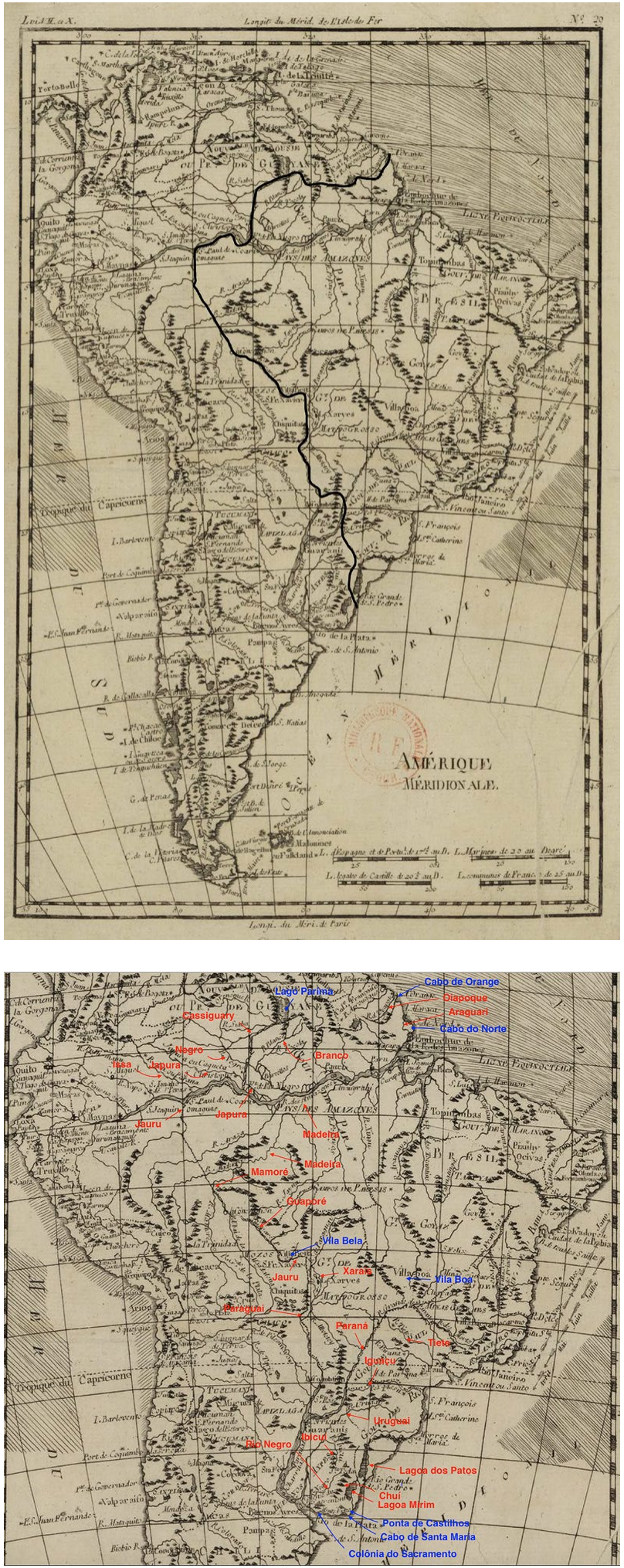

Figure I4. Bonne and Raynal, Amerique Méridionale, 1780. BNF, DCP, H.G.22484v.

The first image presents the the frontier line that was agreed in Santo Ildefonso and El Pardo by D. Francisco and the second the main sites along the border that were used as references to settle the limits. 
The Northern frontier with Guiana is clearly a tributary of Balsemão's vision and is surprisingly pro-Portuguese and detrimental to the French. On the coast, Cape Orange, much more to the north than the North Cape, is chosen for the beginning of the frontier line, which runs southwest and continues parallel to the Southern bank of the Oiapoque. Since Balsemão did not specify the position of the line in relation to the geographic features of the interior, until it reached Cassiguary canal, Bonne traced it along the mountain range, located at the source of the Oiapoque River, mixing what was negotiated with the French in Utrecht and with the Spanish in Madrid. In this way, the mythological Lake Parima, also represented on the maps of Jorge Juan and Cruz Cano, is located in Spanish territory, the Portuguese maintaining the extensive strip on the northern bank of the Amazon, up to the western side of the Japurá River. From the latter point to the confluence with the Javari River, more to the west, it was defined in Santo Ildefonso that the line would run along the Amazon River, the navigation of which would be shared and the Spanish would be the masters of the northern side and the Portuguese the south. However, the line drawn in the Atlas runs below the southern side, a clear advantage for the Castilians, probably inspired by Balsemão's idea to cede the southern bank between Madeira and Napo rivers to the Spanish, but without totally assuming the polemical part of the project, which was never negotiated.

Between the mouth of the Javari River and the confluence of the Iguaçu with the Paraná rivers, which corresponded to the entire frontier of the extreme west, the Atlas followed, roughly speaking, what was stipulated in Santo Ildefonso, a confirmation of what had been negotiated in Madrid, which corresponded to the vision of D. Francisco. However, there are two exceptions. The first is Lake Xarais. In the two treaties and for D. Francisco, the frontier ran through the middle of the lake, which the Portuguese called Pantanal and was a result from the of the full tides of Paraguay. Balsemão did not make any mention of it, stating only that the line followed the river. However, in the Atlas, from Jauru River onwards the line goes to the south passing to the west of Xarais and the Upper Paraguay River, with the Portuguese controlling both sides of the lake and the river. It is not known from where Bonne took this configuration, but certainly it displeased the Spanish. The second resulted from the difficulty in identifying the river, or rivers which served as the line between the Paraguay and Paraná rivers. Balsemão refers to the Ipaniguaçu, a tributary of the Paraguay River, while Bonne bases himself on the map of Cruz and Cano to locate this river. The result is that he embodies the ambassador's project of drawing the line south of the Tropic of Capricorn, but is closer to this parallel than what Balsemão wanted, afterwards running along a tributary of the Paraná River which according to him was the Iguatemi River.

In the Atlas, based on the confluence between the Paraná and the Iguaçu rivers, the line gradually heads to the southeast, until it reaches the canal between Lakes Patos and Mirim. In this section, its upper half is more favor- able to the Portuguese than what was proposed by Balsemão, which advanced the line to the east, until the mouth of the Uruguay River, close to the coast, and even what was negotiated in Santo Ildefonso, where it followed the course of the Iguaçu River to the East until Santo Antônio, its tributary, as stipulated in Article VIII. D. Francisco's proposal is more generous, the line positioned to the West, running south, following the bed of the Uruguay River, as stipulated in Madrid, including Sete Povos das Missões. Its lower half is clearly pro-Spanish: Santo Ildefonso, D. Francisco and Balsemão positioned the limit much more to the south that the isthmus between the two lakes, which are represented in the Atlas. The first locates it on the west bank of Lake Mirim, near the Chuí stream; the second, on Castilhos Point; and the third in Santa Maria Cape, on the mouth of the River Plate, extending Portuguese dominion to this river, which covered, in a discontinuous form, Sacramento Colony, to be exchanged for the territories ceded along the Amazon River. In relation to the latter, the drawing on the Atlas follows what was defended by D. Francisco and stipulated in Santo Ildefonso, where Sacramento Colony was used as a bargaining chip and returned to the Spanish, assuring them exclusive navigation on the River Plate.

While it cannot be securely explained why the map of South America from the Atlas drew the frontier with Guiana against the interests of France, the same cannot be said of the rest of the oscillations sometimes in favor of Portugal, sometimes in favor of Spain. It reflected the fact that the edition of the 1780 Histoire des Deux Indies became a space of dispute between the two Iberian Crowns. At the same time that the Portuguese diplomats, such as D. Francisco, Balsemão, and D. Rodrigo, sought to influence its maps and its text in favor of the Portuguese interest, the Spanish ambassador, the Count of Aranda sought to mold the Abbé's work in favor of the Castilians (Quérard, 1835, p. 474); Furtado and Monteiro, 2019, pp. 14-15). Oscillating between one side and the other, the Atlas de Toutes les Parties Connues du Globe Terrestre was not a neutral space for the pure representation of physical geography, but expressed and was involved in the geopolitical disputes of the European metropoles in South America.

\section{ACKNOWLEDGEMENTS}

I would like to thanks CNPq, FAPEMIG and CAPES for scientific support. This article is part of the research $\mathrm{R}+\mathrm{D}+\mathrm{i}$ Project CARTOPOLIC "Cartografías en movimiento. Circulación y construcción de los saberes geográficos en las monarquías policéntricas ibéricas" (UPO-1260972) funded by European Regional Development Fund (ERDF), Operational Programme 2014-2020 Junta de Andalucía.

\section{NOTES}

1 Biblioteca da Ajuda, Lisboa (BA), Extrait des Notes, 54-XI26(7), fs. 1-36v; Mémoires, 54-XI-27 (11), fs. 1-10v

2 Bibliothèque Nationale de France, Department des Cartes et Plans, Paris (BNF, DCP), d'Anville, J. B. B. (1760) Amérique 
Méridionale, D’Anville, 1760. GE DD 2987 (9168B).

3 N.A., (1772) Carte du Brésil, première partie, depuis la rivière des Amazones jusqu'à la Baie de Tous les Saints. Amsterdam.

4 BNF, DCP, d' Anville, J. B. B. (1748) Suite du Brésil. From "Amérique Méridionale." Paris.

5 D’Anville, J. B. B. (1748) Suite du Brésil, depuis la baie de Tous les Saints jusqu’à St. Paul. From the "Amérique Méridionale." Paris.

6 BNF, DCP, d'Anville, J. B. B. (1745) Carte du cours du Maragnon ou de la Grande Rivière des Amazones, according La Condamine between 1743 and 1744. Paris.

7 BNF, DCP, n.a. (1772) Carte du Paraguay et des Pays voisins. Amsterdam.

8 Like Carte du Paraguai, it was produced for the Jesuits and published in the 1733 volume of Recueil des Lettres édifiantes, and Amérique Méridionale (Furtado, 2013, pp. 81-82).

9 In BNF, under call number H.G.22484v, there is an example of the 1780 edition with 50 maps. The surplus map represents the French islands close to Madagascar.

10 Also included was the cession to the Spanish of the islands of Fernando Pó and Ano Bom in West Africa.

11 Arquivos Nacionais da Torre do Tombo, Ministério dos Negócios Estrangeiros, Legação de Madrid, Lisboa (ANTT, MNE, LM), Cartas do Embaixador D. Francisco de Sousa Coutinho para Ayres de Sá e Melo, Santo Ildefonso, 8/8/1777, Caixa 629.

12 ANTT, MNE, LM, Cartas do Embaixador, Escorial, 9/11/1777.

13 ANTT, MNE, LM, Cartas do Embaixador Aranjuez, 5/6/1777; Madrid 11/4/1777; Aranjuez, 5/6/1777; Madrid, 11/7/1777; Santo Ildefonso, 5/9/1777, Caixa 629; Aranjuez, 25/5/1778, Caixa 630, n.75; Madrid, 26/2/1779, Caixa 631, n.17; Santo Ildefonso, 8/8/1777 and 5/9/1777; Avisos do Reino, Lisboa, 24/5/1777, 17/6/1777, Caixa 615

14 Probably the map entitled Mappa geographico da campanha por donde marchou o xercito de S. Magestade Fidelisima sahindo do Río Grande de Sam Pedro, a quem auxiliava contra os sette povos rebeldes situados na margen oriental do Río Uruguay elevada pelo tenente coronel...José Custodio de Sá e Faria. Desenhada por Manoel Vieyra Leao, 1758. His size is 34 X 38 cm. Arquivo Geral de Simancas. MPD, 18, 014 (Garcés, 2016, p. 303).

15 ANTT, MNE, LM, Avisos do Reino, Ajuda, 18/6/1777, Caixa 615; Cartas do Embaixador, Madrid, 11/7/1777; Santo Ildefonso, 8/8/1777; Santo Ildefonso, 5/9/1777 e 20/11/1777, Caixa 629.

16 ANTT, MNE, LM, Cartas do Embaixador, Aranjuez, 27/5/1778, Caixa 630, n.76; Santo Ildefonso, 8/8/1777, Caixa 629.

17 ANTT, MNE, LM, Cartas do Embaixador, Vila Viçosa, 24/10/1777; Madrid, 22/1/1779, Caixa 631, n.8.

18 ANTT, MNE, LM, Cartas do Embaixador, Santo Ildefonso, 8/8/1777 and 23/9/1777; Madrid, 31/3/1777, 11/4/1777 and 30/5/1777, Caixa 629

19 ANTT, MNE, LM, Avisos do Reino, Ajuda,15/9/1777; Vila Vicosa, 24/10/1777, Caixa 615

20 ANTT, MNE, LM, Cartas do Embaixador, Madrid, 11/4/1777, Caixa 629.

21 ANTT, MNE, LM, Cartas do Embaixador, Madrid, 11/4/1777, Caixa 629

22 ANTT, MNE, LM, Avisos do Reino, Ajuda,15/9/1777, Caixa 615; Cartas do Embaixador, Madrid, 11/4/1777, Caixa 629; Madrid, 26/2/1779, Caixa 631, n.17; Santo Ildefonso, 7/8/1776, Caixa 618

23 In addition, there are copies in the Library of Congress, Universidad Complutense de Madrid, Universidad de la de Granada and Biblioteca Nacional de Espanha, under call number bdh0000001180, which can be consulted online.

24 Carte Reduite de l'Ocean Meridional Compris entre l'Afrique et l'Amerique Méridionale (1742), Paris.

25 Bellin, M. Carte de Amérique Méridionale (1756), Paris; Anville, J.B.B. Amérique Méridionale (1749); Green, Chart of South America comprehending the West Indies, with the Adjacent Islands in the Southern Ocean, and South Sea (1753), London.
26 ANTT, MNE, LM, Cartas do Embaixador, Madrid, 11/4/1777, Caixa 629.

27 D. Vicente had already sent a manuscript copy to Portugal in April 1776, before the book had been printed, calling it "a pedantific (sic) and sophisticated Book or Manifesto which the Count of Aranda [the Spanish ambassador in Paris] had printed in Paris on the Demarcation of the Dominions of the two Monarchies.” ANTT, MNE, Legação de Paris (LP), Livro 699. In September 1776, D. Francisco sent to Aires de Sá "a book which has now come out here", so that he could order "what was of service", this could be the book of Ulloa and Juan. ANTT, MNE, LM, Cartas do Embaixador, 24/10/1777, Caixa 615; Santo Ildefonso, 7/8/1776, Caixa 618.

28 ANTT, MNE, LM, Avisos do Reino, Ajuda, 21/4/1777 and 15/9/1777, Caixa 615

29 Igurei or Igurey and Correntes or Corrientes. The fact that those rivers didn't exist brought a lot of problems to the Luso-Castilian Demarcation Expeditions in the south of Brazil after Saint Ildefonso Treaty led to the abandon of the Portuguese representatives (Garcés, 2016, pp. 517-518).

30 ANTT, MNE, LM, Cartas do Embaixador, Aranjuez, 27/5/1778, Caixa 630, n.76; Avisos do Reino, Ajuda, 3/5/1777 and 8/6/1778, Caixa 615 (original emphasis).

31 ANTT, MNE, LM, Cartas do Embaixador, Aranjuez, 27/5/1778, Caixa 630, n.76; 1/6/1778, Caixa 630, n. 86.

32 Garcés sustained there were two printings in latte 1775 , one in November and one in December. The first used paper from Holland that blurred the drawing. Both were only proofs of the map (Garcés, 2016, pp. 456-457; Donoso, 1963, p. 154).

33 The only two copies of the 1775 's original edition with the border line drawn are in Harvard and Newberry (Ayer Collection) Libraries (Smith, 1966, pp. 59, 62).

34 Smith found the total of 31 alterations. Some concerning geographical mistakes, many corrections suggested by Ulloa, and some the bordering limits as they were in favor of the Portuguese claims (Smith, 1966, pp. 58-62; Garcés, 2016, pp. 498-503)

35 Donoso says of 7 copies (Donoso, 1963, pp. 127, 157) and Garcés of 14, 7 with the 8 sheets put together (montados) as a mural map, better to draw the border line, and 7 with the sheets bound (encadernados) as an Atlas (Garcés, 2016, p. 505).

36 Cartas do Embaixador ao marquês de Pombal, Madrid, 27/2/1776, Caixa 628. Two years later, Cevallos left it to his successor "to help in the demarcations of frontiers" (Almeida, 2009, pp. 85-86).

37 ANTT, MNE, LM, Cartas do Embaixador, Santo Ildefonso, 7/8/1776, Caixa 618; Madrid, 28/3/1777; Aranjuez, 11/6/1777; Madrid, 26/8/1777, Caixa 629.

38 ANTT, MNE, LM, Cartas do Embaixador, Madrid, 1/1/1776, Caixa 628; Madrid, 28/3/1777, Caixa 629; 15/1/1779, Caixa 631, n.6.

39 ANTT, MNE, LM, Cartas do Embaixador, Santo Ildefonso, 11/6/1777; Aranjuez, 25/3/1777. Santo Ildefonso, 11/6/1777, 18/6/1777, 8/8/1777, 22/8/1777, Caixa 629; 24/6/1778, Caixa 630, n. 91.q.

40 BA, Mémoires, 54-XI-27 (11), fs. 1-10v; Extrait des Notes, 54XI-26 (7), fs. 11v-14.

41 BA, Extrait des Notes, 54-XI-26 (7), f. 11v.

42 BA, 54-XI-26(7), f. 13

\section{REFERENCES}

Almeida, A. F. de. (2009) "O Mapa Geográfico de América Meridional, de Juan de la Cruz Cano y Olmedilla." Anais do Museu Paulista, 17 (2), pp. 83-86.

Aquarone, J.-B. (1972) "L'Abbé Raynal et le Portugal." In: A. Labertit, ed., Tilas, Vasco da Gama (1469-1969), Actes du Colleque de Strasbourg, XII, pp. 81-92.

Aspinall-Oglander, C. (1942) Admiral's Widow, Being Life and Letters of the Hon. Edward Boscawen from 1761 to 1805. Londres.

Bély, L. (1990) Espions et Ambassadeurs au Temps de Louis XIV. Paris: Fayard. 
Bonne, R. (1780) "Analyse Succint de cet Atlas." In: R. Bonne and G.-T. Raynal, Atlas de Toutes les Parties Connues du Globe Terrestre: Dressé pour l'Histoire Philosophique et Politique des Établissements et du Commerce des Européens dans les deux Indes de Guillaume Thomas Raynal. Genève: J.-L. Pellet, pp. $1-23$.

Bonne, R. and Raynal, G.-T. (1780) Atlas de Toutes les Parties Connues du Globe Terrestre: Dressé Pour l'Histoire Philosophique et Politique des Établissements et du Commerce des Européens dans les Deux Indes de Guillaume Thomas Raynal. Genève: J.-L. Pellet.

Brito, A. J. I. (2018) "Guerra, Fiscalidade e Dinâmicas Transfronteiriças no Vale Ibero-Americano do Alto Amazonas, 1763c.1772." In: A. J. I. Brito and C. A. Bastos, eds., Entre Extremos: Experiências Fronteiriças e Transfronteiriças nas Regióes do Rio Amazonas e do Rio da Prata-América Latina, Séculos XVI$X X$. Curitiba: CRV.

Brown, A. (2010) "Atlas de Toutes les Parties Connues du Globe." In: R. Bonne and G.-T. Raynal, Atlas de Toutes les Parties Connues du Globe Terrestre: Dressé pour l'Histoire Philosophique et Politique des Etablissements et du Commerce des Européens dans les deux Indes de Guillaume Thomas Raynal. Paris: Centre International d'Étude du XVIIIe siècle Ferney-Voltaire, pp. 39-41.

Bueno, B. P. S. (2008) "O Engenheiro Artista: As Aquarelas e as Tintas nos Mapas do Novo Mundo.” In: J. F. Furtado, ed., Sons, Formas, Cores e Movimentos na Modernidade Atlântica: Europa, Américas e África. São Paulo: Annablume, pp. 375-383.

Cañizares-Esguerra, J. (2001) How to write the History of the New World. Stanford: Stanford University Press.

Costa, J., ed. (2000) A Terra de Vera Cruz, Viagens, Descrições e Mapas do Século XVIII. Porto: Biblioteca Pública do Porto.

Costa, J. M. R. (2012), "Alguns Livros Científicos (Sécs. XVI e XVII) no 'Inventário' da Livraria dos Viscondes de Balsemão." Ágora. Estudos Clássicos em Debate, 14 (1), pp. 131-158.

Coutinho, A. S. A. (2009) "Imagens de França do Século XVIII através da Colecção Cartográfica do Visconde de Balsemão." Revista da Faculdade de Letras, 3 (10), pp. 17-27.

Diniz Silva, A. M. (2003) Portrait d'un Homme d'État: D. Rodrigo de Souza Coutinho, Comte de Linhares (1755-1812). Lisboa: Fundação Calouste Gulbenkian, tomo I.

Diniz Silva, A. M. (2006) Portrait d'un Homme d'État. Lisboa: Fundação Calouste Gulbenkian, tomo II.

Donoso, R. (1963) "El mapa de la América meridional de la Cruz Cano y Olmedilla." Revista Chilena de Historia y Geografía, 131, pp. 120-175.

Feugère, A. (1970) "L'Art d'Utiliser les Hommes: Raynal et ses Collaborateurs." In: L'abbé Raynal: un Précurseur de la Revolution. Genève: Slatkine Reprints, pp. 175-200.

Furtado, J. F. (2012) Oráculos da Geografia iluminista: Dom Luís da Cunha e Jean Baptiste Bourguignon D'Anville na Construção da Cartografia do Brasil. Belo Horizonte: Ed. UFMG.

Furtado, J. F. (2013) The Map that Invented Brazil. São Paulo/Rio de Janeiro: Odebrecht/Versal.

Furtado, J. F. and Monteiro, N. G. (2016) "The Different Brazils in Abbé Raynal's Histoire des Deux Indes." Varia Historia, 32 (60), pp. 731-777.

Furtado, J. F. and Monteiro, N. G. (2019) "Raynal and the Defence of the Portuguese Colonization of Brazil: Diplomacy and the Memoirs of the Visconde de Balsemão." Análise Social, 230, pp. 4-33.

Furtado, J. F. and Paquette, G. (2019) "Imperial Competition in the Eighteenth-Century Americas.” In: F. Bouza, P. Cardim and A. Feros, eds., The Iberian World. New York/London: Routledge, pp. 519-540.

Garcés, J. A. J. (2016) La obra del cartógrafo Cano y Olmedilla y su mapa de la América meridional de 1775. Madrid: Universidad Complutense de Madrid.

Garcia, J. C., ed. (2011) Cartografia do Brasil na Biblioteca Pública Municipal do Porto. Porto: Biblioteca Pública do Porto/Faculdade de Letras da Universidade do Porto.
Giraldo, M. L. (1991) Ilustrados y Bárbaros: Diario de la Exploración de Limites al Amazonas (1782). Madrid: Alianza Editorial.

Goggi, G. (2000) "Autour du Voyage de Raynal en Angleterre et en Hollande: la Troisième Edition de l'Histoire des Deux Indes." In : G. Bancarel and G. Goggi, eds., Raynal: de la Polemique à L'histoire. Oxford: Voltaire Foundation, pp. 371-425.

Goggi, G. (2010) "L'Abbé Raynal et un Questionaire sur le Portugal et sur le Brésil." Studi Settecenteschi, 27-28, pp. 285-316.

Gómez, L. J. R. (1995) "Jorge Juan y Antonio de Ulloa y el Meridian de Tordesillas: La Disertación Histórica y Geográfica (1747-1776)." In: El Tratado de Tordesillas y su época. Madrid: Sociedad V Centenario del Tratado de Tordesillas, tomo VI, pp. 1561-1592.

Israel, J. (2011) Democratic Enlightenment. Philosophy, Revolution, and Human Rights (1750-1790). Oxford: Oxford University Press.

Juan, J. and Ulloa, A. de. (1749) Disertación Histórica y Geográfica sobre el Meridiano de Demarcación entre los Dominios de España y Portugal y los Parajes por donde passa en la America Meridional conforme á los Tratados y Derechos de cada Estado, y las más Seguras y Modernas Observaciones. Madrid: Imprenta de Antonio Marín.

Juan, J. and Ulloa, A. de. (1776) Dissertation Historique et Géographique sur le Méridien de Démarcation entre les Domaines d'Espagne et de Portugal. Paris: A. Boudet.

Kantor, I. (2016) "Impérios Portáteis: Três Atlas na era das Revoluções Atlânticas." In: A. B. Xavier and C. N. da Silva, eds., O Governo dos Outros. Poder e Diferença no Império Português. Lisboa: Imprensa de Ciências Sociais, pp. 503-522.

Mackinlay, A. (2011) El Best-Seller que Cambió el Mundo. Globalización, Colonialismo y Poder en el Siglo de las Luces. Amazon for Kindle.

Magalhães, J. C. (1990) "A acção diplomática no pensamento dos diplomatas portugueses dos séculos XVII e XVIII." In: A diplomacia na História de Portugal: Actas do Colóquio. Lisboa: Academia Portuguesa da História, pp.14-27.

Mitchell, K. (1999) "Science, Giants and Gold: Juan de la Cruz Cano y Olmedilla's Mapa Geografico de la America Meridional", Terra Incognita, 31, pp. 6-22.

Muthu, S. (2003) Enlightenment Against Empire. Princeton: Princeton University Press.

Quérard, J.M. (1835) La France Littéraire ou Dictionnaire Bibliographique des savants, Paris: Firmin Didot, tomo VII.

Ramos Perez, D. (1974) "Los Criterios Contrarios al Tratado de Tordesillas en el Siglo XVIII. Determinantes de la Necesidad de su Anulación." Revista da Universidade de Coimbra, 25, p. $1-34$

Raynal, G.-T. (1773) Atlas Portatif pour Servir à L'intelligence de l'Histoire Philosophique et Politique des Établissements et du Commerce des Européens dans les Deux Indes. Amsterdam: E. Van Harrevelt e D. J. Changuion,.

Raynal, G.-T. (1774) Histoire Philosophique des Établissements et du Commerce des Européens dans les Deux Indes. Haia: Gosse fils, 6 tomos.

Raynal, G.-T. (1780) Histoire Philosophique des Établissements et du Commerce des Européens dans les Deux Indes. Genève: J.-L. Pellet, 9 tomes.

Rodrigues, C. (2020) "Ideia Geographica dos Territorios Portuguezes que Comprehende o Governo e Capitania General do Matto Grosso e Cuiaba】. Confinantes as Provincias Castelhanas de Chiquitos e de Mojos." LaborHistórico, 6 (1), pp. 315-327.

Santos, L. C. V. G. (2018) Juca Paranhos, o Barão do Rio Branco. São Paulo: Companhia das Letras.

Smith, T. R. (1966) "Cruz Cano's Map of South America, Madrid, 1775: Its Creation, Adversities and Rehabilitation." Imago Mundi, 20, pp. 49-77.

Tapia, A. S. (1995) "La Delimitación Definitiva de Tordesillas: El Tratado de San Ildefonso (1777)." In: El Tratado de Tordesillas y su época, tomo VI, pp. 1669-1670. 